\title{
The direction of ecological insurrections: political ecology comes to daggers with Fukuoka
}

\author{
Alexander Dunlap ${ }^{1}$ \\ University of Oslo, Norway
}

\begin{abstract}
This article proposes a political ecology of resistance. This is done by putting forward insurrectionary political ecology as a lens of research and struggle, through the confluence of the complementary "political" practice of insurrectionary anarchism and the "ecological" method of "no-till natural farming." While seemingly different, the article argues that these practices are compatible, animating a political ecology of resistance around antiauthoritarian political and ecological lifeways. This direction, or compass, of insurrectionary political ecology is discussed in relation to other autonomous tendencies, as it complements and strengthens existing critical schools of thought heavily influenced by political ecology, such as (decolonial) degrowth, environmental justice and post-development. Insurrectionary political ecology deepens connections with scholarly rebels in political and ecological struggles outside—and rejecting - the university system. The article includes discussions of research ethics, various conceptions of "activism", autonomous tendencies and existing differences between the concepts of "revolution" and "insurrection", in order to debate notions of "counter-hegemony" and "duelpower." The overall purpose here is to offer a theoretical ethos for a political ecology of resistance that invigorates political praxis to subvert the ongoing socio-ecological catastrophes.
\end{abstract}

Keywords: Resistance; insurrectionary political ecology; post-development; decolonization; degrowth; insurrectionary ecology; environmental justice

\section{Résumé}

Cet article propose une écologie politique de la résistance. Cela se fait en proposant «l'écologie politique insurrectionnelle» comme un prisme de recherche et de lutte, à travers la confluence de la pratique politique de l'anarchisme insurrectionnel et de la méthode «écologique» de «l'agriculture naturelle sans labour». Bien qu'en apparence différentes, l'article soutient que ces pratiques sont compatibles, animant une écologie politique de la résistance autour de modes de vie politiques et écologiques anti-autoritaires. Cette direction, ou boussole, de l'écologie politique insurrectionnelle est discutée en relation avec d'autres tendances autonomes. Il complète et renforce les écoles de pensée fortement influencées par l'écologie politique, telles que la décroissance, la justice environnementale et le post-développement. L'écologie politique insurrectionnelle approfondit les liens avec les «rebelles savants» dans les luttes politiques et écologiques en dehors du système universitaire. L'article traite de l'éthique de la recherche, des différentes conceptions de «l'activisme», des tendances autonomes et des différences existantes entre les concepts de «révolution» et d '«insurrection». Je débat des notions de «contrehégémonie» et de «duel-pouvoir». Le but est de proposer une éthique théorique pour une écologie politique de la résistance, qui dynamise la praxis politique pour renverser les catastrophes socio-écologiques en cours.

Mots-clés: Résistance; écologie politique insurrectionnelle; post-développement; décolonisation; décroissance; écologie insurrectionnelle; justice environnementale

\section{Resumen}

\footnotetext{
${ }^{1}$ Dr. Alexander Dunlap, post-doctoral research fellow, Centre for Development and the Environment (SUM), University of Oslo, Norway. Email: alexander.a.dunlap "at" gmail.com. His work has critically examined police-military transformations, market-based conservation, wind energy development and extractive projects more generally in both Latin America and Europe. Special thanks and appreciation to the reviewers and to the editors of the Journal of Political Ecology for their support and formatting/editorial work.
} 
Este artículo hace una propuesta general sobre una ecología política de la resistencia. Esto se hace presentando la ecología política insurreccional como una lente de investigación y lucha, a través de la confluencia de la práctica "política" complementaria del anarquismo insurreccional y el método "ecológico" de la " siembra directa." Aunque aparentemente diferente, el artículo sostiene que estas prácticas son compatibles, animando una ecología política de la resistencia en torno a formas de vida políticas y ecológicas anti-autoritarias. Esta dirección, o brújula, de la ecología política insurreccional se discute en relación con otras tendencias autónomas, ya que complementa y fortalece las escuelas críticas de pensamiento existentes fuertemente influenciadas por la ecología política, como el decrecimiento (decolonial), la justicia ambiental y el posdesarrollo. La ecología política insurreccional profundiza las conexiones con los eruditos rebeldes en las luchas políticas y ecológicas fuera del sistema universitario y que, además, lo rechazan. Este artículo incluye discusiones sobre ética de la investigación, diversas concepciones de "activismo", tendencias autónomas y diferencias existentes entre los conceptos de "revolución" e "insurrección", con el fin de debatir las nociones de "contrahegemonía" y "poder dual." El propósito general es ofrecer un ethos teórico para una ecología política de la resistencia que vigoriza la praxis política para subvertir las catástrofes socioecológicas en curso.

Palabras clave: Resistencia; ecología política insurreccional; posdesarrollo; descolonización; decrecimiento; ecología insurreccional; la justicia ambiental

\section{Introduction}

Whether you turn inward or outward, whatever you encounter, kill it! If you meet a Buddha, kill the Buddha; if you meet a Patriarch, kill the Patriarch; if you meet an enlightened being, kill the enlightened being; if you meet your parents, kill your parents; if you meet your relatives, kill your relatives. Only then will you find emancipation, and by not clinging to anything, you will be free wherever you go. — Linji, Chan Buddhist (d. 867)

Hurry up, comrade, shoot at once on the policeman, the judge, the wealthy, before a new police will hinder you. Hurry up and say no, before a new repression convinces you that to say no is nonsensical and crazy and that you should accept the hospitality of an asylum. Hurry up and attack the capital, before a new ideology makes it sacred for you. Hurry up and refuse work, before a new sophist tells you: Work makes you free. Hurry up and play. Hurry up and arm yourself. - Alfredo Bonanno, Armed joy (1977)

Trying to separate humans from "nature" is as misguided as attempting to separate theory from action. Reconciling these two separations, while altering our socio-political values towards sharing, actively respecting nature and each other ${ }^{2}$ is the central individual and collective challenge that humans are currently facing, as the planet plummets towards ecological, climate and pandemic catastrophe. According to the United Nations (UNSDG 2018): "degradation of dry lands has led to the desertification of 3.6 billion hectares", as "[n]ature across most of the globe has now been significantly altered by multiple human drivers, with the majority of indicators of ecosystems and biodiversity showing rapid decline" (IPBES 2019: 3). The cause, however, is less abstract than climate modeling, statistical data and academic reports would ever acknowledge: it is the values, organization and operation of techno-industrial society itself. ${ }^{3}$ It is the production, reproduction and habitual patterns of capitalist development to which many of us have grown so dependent and accustomed.

\footnotetext{
${ }^{2}$ In jargon: social cultural values predicated on egalitarianism, biocentrism and convivial socio-technological development.

${ }^{3}$ Values and forms of organization that are traceable to ancient civilizations.
} 
Stopping this one-way ticket to oblivion is the true challenge. Apathy, disinterest and political conformity proliferate, while social media has blossomed as central to (mainstream) oppositional politics within industrial society. This is because, as Seaweed (2013: 19) rightly points out, the "world's population consists of defeated peoples in this war", which is "more than just defeated. We are kept: kept in fear, kept in awe, kept out of touch with each other and the earth that gives us life." Over centuries, people have "internalized much of the values and ideas of the conquerors and have thus been assimilated into the ways of the obedient and the domesticated" (Seaweed 2013: 19; see Gelderloos 2017). The "war" that Seaweed refers to is both an ancient conventional war, but also the ever-present social war designed to disrupt social fabrics, manage subjectivities and assimilate populations into statist and market structures (Gardenyes 2011, 2012; Dunlap 2019a). The "military's [physical and cultural] infiltration into the movements of daily life", Paul Virilio (1990 [1978]) explains, "reproduce[s] the metamorphoses of the hunter: from direct confrontation of the wild animal; to progressive control over the movements of certain species; then, with the help of the dog, to guarding semiwild flocks; and finally to preproduction, breeding" (see also Bæedan 2014). To be clear, this is an alienated hunter separated from ecosystem immersion, enacting practices of domination imbued with a logic of the market, or accumulation, which bleeds insecurity, enacting control strategies and systems. Techno-capitalist society has domesticated a civil population, circumscribing self-determination, mediating agency and redirecting initiative through institutional, social and (bio)political arrangements to propel technological and capitalist development. Riots breaks out and (autonomous) space is captured for moments or months, yet the struggle to maintain and transform this space remains a challenge. How does the burned down Wendy's ${ }^{4}$ transform into a community garden? By dispensing new qualities of food and social relationships, as opposed to fast food.

While speaking indirectly to this question of socio-ecological transformation, this article proposes an open-ended and experimental proposal, conceiving a political ecology theory of resistance. I develop the concept of insurrectionary political ecology, demonstrating the complementary practices of "no-till natural farming" and insurrectionary anarchism. The article seeks to argue for their compatibility, by describing how these ecological and political practices should serve as directional ideals for an anti-authoritarian political ecology of resistance. This includes opening up the question of organizational strategies for further reflection and experimentation. Political ecology, more than most disciplines and frameworks, is already related, intertwined and contributing to environmental, indigenous and other "societies in movement" (Zibechi 2012: 208). This direction, or compass, overlaps with, complements and should serve to strengthen the existing critical schools of thought that are heavily influenced by political ecology, such as (decolonial) degrowth (D'Alisa et al. 2014; Nirmal and Rocheleau 2019) and post-development practices (Rahnema and Bawtree 1997; Kothari et al. 2018; Klein and Morreo 2019). Insurrectionary political ecology seeks to deepen connections with scholarly rebels in political and ecological struggles outside the university system, even rejecting that system. The purpose here is twofold: to offer a theoretical ethos for a political ecology of resistance, and to invigorate a political organizational praxis aiming to subvert socio-ecological catastrophe (Figure 1).

The next sections situate a political ecology of resistance. Following this, the concepts of "do nothing" natural farming and insurrectionary anarchism are explored, through an analysis of Masanobu Fukuoka's (2010 [1978]) The One Straw Revolution and various insurrectionary anarchists texts, such as the Anonymous (2001 [1998]) booklet: At Daggers Drawn: with the existent, its defenders, and its false critics. The two concepts come into dialogue with each other in the subsequent section, discussing their philosophical commonalities and differences. Considering the sensitive, difficult and—for many— "impossible" relational direction advocated by natural farming and insurrectionary anarchism, the conversation focuses on the challenges faced by insurrectionary political ecology within the current institutional and political context. The article concludes by reviewing insurrectionary political ecology and by offering ways to move forward as a discipline. The graffiti sprayed on the walls of Paris during the May 1968 insurrection: Be realistic - demand the impossible (!), should

\footnotetext{
${ }^{4}$ A North American fast food restaurant chain founded in 1969. A Wendy's was burnt down by protesters angry at the police shooting of an African American, Rashard Brooks, at a restaurant in Atlanta, USA in June 2020. https://www.theguardian.com/world/2020/jun/14/rayshard-brooks-shooting-protesters-set-fire-to-restaurant-where-black$\underline{\text { man-shot-dead }}$
} 
not only guide the reading of this text, but also the ways we imagine and work towards an alternative present and future. As Ward Churchill (2003: 272) reminded us: "you must never allow your oppressor to define what's "realistic" for you." Imaginations, capabilities and ideas should not be constrained by "practicalities" or "realism", even if their confrontation is inevitable.

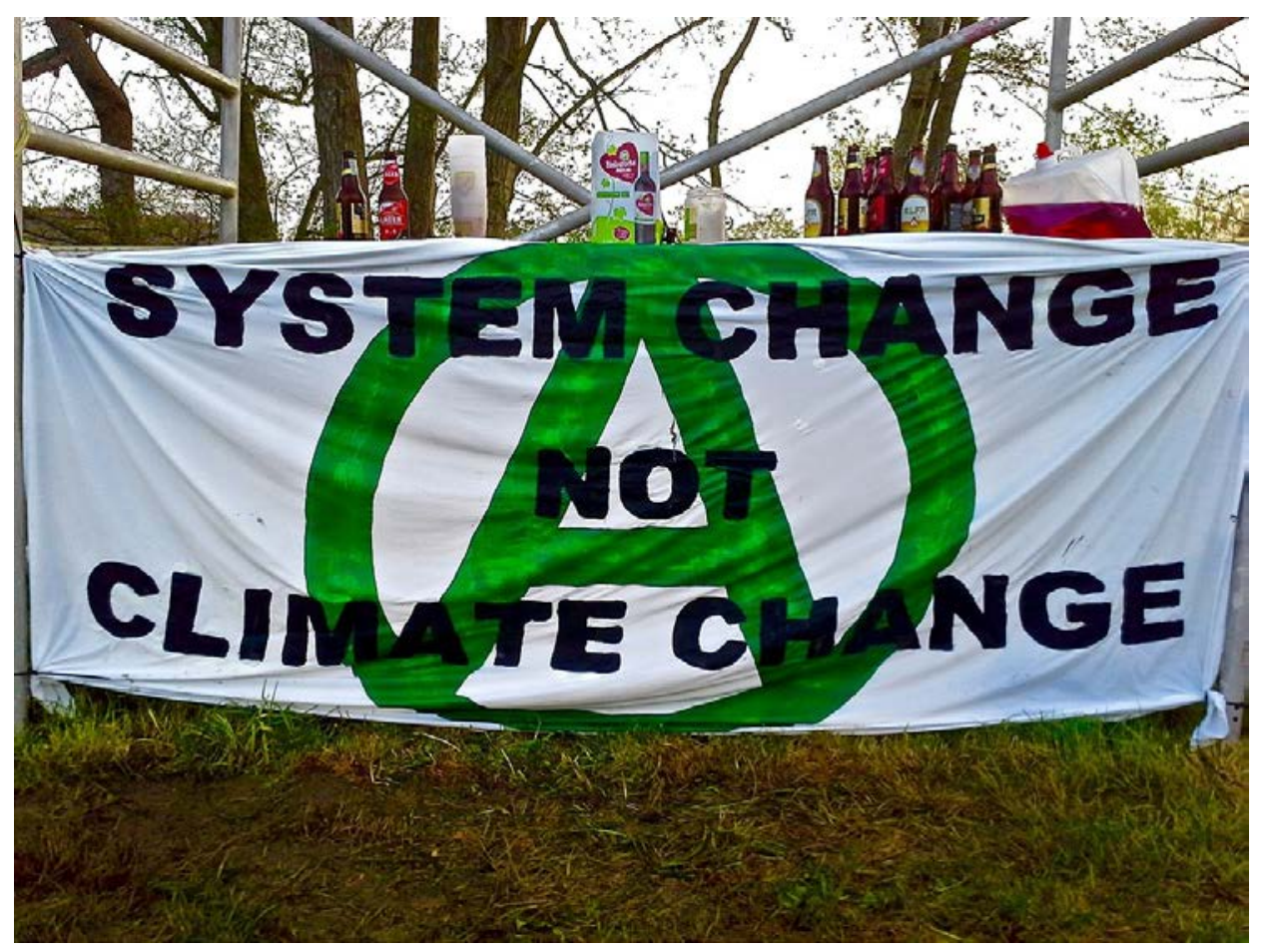

Figure 1: Banner from the inhabited Hambach forest. Source: Wikimedia Commons.

\section{Political ecology and resistance}

Control-authority and power-are fascinating to political ecologists (see Svarstad et al. 2018). While the field is well versed-maybe better than any other-in understanding the variegated processes of "conventional" and "green" natural resource control and governance (see Bebbington and Bury 2013; Dunlap and Jakobsen 2020), it takes a relatively ambiguous position on resistance. ${ }^{5}$ Ambiguity, however, allows openness and fluidity that supports a pluriverse of various forms of resistance, "counter-conduct" (Foucault 2007: 204), evasive maneuvering (Scott 2009) and "attack"6 to unfold. Undoubtedly, this is political ecology's strength. The field is influenced by the student, anti-war and environmental movements of the 1960s to the 1980s. It emerged as a reaction to the methodological shortcomings of ecology (Perreault et al. 2015), famously challenging the surreptitious "apolitical ecology" dominant within the academy (Robbins 2004). Political ecology is an evasive academic field, jumping between anthropology, geography, ecology and development studies, while providing in the process a critical scholarly space within those disciplines. Political ecology is largely fieldwork-based and "politically engaged", dispelling the technocratic myths of objectivity, challenging epistemic violence and attempting to provide an honest, holistic and critical perspective to the socio-ecological issues of our times. This has led many to claim (see Perreault et al. 2015) that those who identify as political ecologists do not only want to understand the world, but to change it as well.

\footnotetext{
${ }^{5}$ Ted Trainer (2019a, 2019b) is a notable exception.

${ }^{6}$ Resistance implies reaction, while attack takes initiative and is self-determined: "Being the aggressor prevents one from victimizing oneself" (Schwarz et al. 2010: 65).
} 
Rooted in research geared towards supporting social justice (Peet and Watts 2004 [1996]), influenced by Marxian and anarchist theory (see Leff 2015; Dunlap and Jakobsen 2020: 50-57), political ecology supports entire oppositional schools of thought. These include feminist political ecology (Rocheleau et al. 1996; Elmhirst 2011), environmental justice (Martinez-Alier 2002; Porto et al. 2017), (decolonial) degrowth (D'Alisa et al. 2014; Nirmal and Rocheleau 2019), post-development thinking (Rahnema and Bawtree 1997; Kothari et al. 2018; Klein and Morreo 2019) and, more recently, convivial conservation (Büscher and Fletcher 2020). There are affinities among political ecologists and resistance movements such as Earth First! (London 1998; Heynen and Van Sant 2015), eco-anarchism (Clark 2019; Trainer 2019a, 2019b; Dunlap, 2019c), the anti/alterglobalization movements (Sullivan 2004), indigenous land struggles, notably Buen Vivir (Escobar 2012 [1995]; Kothari et al. 2014), among Afro-Colombian communities (Escobar 2008), the Zapatistas (Rocheleau 2015) and other (autonomous) movements struggling against land control (Aguilar-Støen 2015; Berlan 2016; Brock and Dunlap 2018; Dunlap 2018a, 2020a; González-Hidalgo and Zografos 2017). Political ecology values the knowledge and struggles of social movements, matching them with critical analysis.

Political ecology has been termed "activist" by Ben Wisner (2015: 56). Nik Heynen and Levi Van Sant (2015: 177) take this further by arguing, "direct action as concept and practice offers a way to further expand the connections between political ecology and activism." Moreover, Heynen and Van Sant (2015: 177) recognize the criticism that "politics within political ecology are overly simplified", responding that "direct action helps to differentiate many forms of politics that too often get lumped together." The insurrectionary political ecology proposal presented below offers greater precision within oppositional direct-action politics, while building a connection between two distinct "political" and "ecological" literatures largely developed outside the academy: insurrectionary anarchism and natural farming. Building on a "political ecology of the state" (Mullenite 2016: 382), Antonio Ioris views the states' historical development and present operational class commitments as "fundamentally at odds with genuine desires for ecosystem protection." This article offers a general sketch and trajectory for a political ecology of resistance through insurrectionary political ecology. Related to "revolutionary environmentalism" (Best and Nocella 2006), insurrectionary political ecology is an academic extension and complementary contribution to "insurrectionary ecology" (Anonymous, n.d.) and "insurrectionary subsistence" (Seaweed 2013), adding to (a non-primitivist) green anarchism (see Green Anarchy 2005, 2012; Return Fire 2013-present and Black Seed, 2014-present). Insurrectionary political ecology seeks to encourage self-refection, embodiment, individual and collective practices, encouraging a sensitivity to power relationships and historical place within our respective circumstances. There are, however, some important considerations concerning the significance of the terms "research", "activism" and "insurrection" to address before exploring a theory of insurrectionary political ecology.

\section{A few side notes to consider}

When investigating societies engaged in movements or direct actions, caution is needed when applying the research gaze to rebellious activities and criminalized identities. Making political activities, group dynamics and the struggles of vulnerable populations visible risks having researchers become tools for authorities to generate "open source intelligence" (Boyce and Cash 2013: 245-246). This risk suggests repositioning the research gaze to generate critical, if not insurrectionary, knowledge. Research revealing the "hidden" governmental, financial and corporate activities are likely to be more effective in supporting rebellious movements (see Dunlap 2018c, 2019a: 10-14). This extends decolonial methodologies, asserting that "research done with instead of on people and communities is ethical, and produces better science" (Zanotti et al. 2020: 45). It should also be remembered, as in non-Indigenous societies, that there are a multiplicity of political ideologies, traditions and agendas when working within state institutions or NGOs (see IAM 2014; Dunlap, forthcoming). This means reconsidering researchers' positionality, ambitions, ethics and purpose when examining rebellious and criminalized movements.

This extends to the concept of "activism" itself, as critical engagement with this concept is generally lacking within political ecology. "Activism" embodies a particular relationship, positionality and identity within capitalist society. While this identity can be empowering as well as disabling, it risks turning activity into a "thing", a distinct category of activity_-"doing activism"—-when we might conceive political action as 
embodied in everyday and normalized activities. This suggests a subtle relational and subjective self-conception and anchoring, rather than separating life activities from the whole (see Andrew X 2009 [1999]; Goldman 2010). "Activism" is heavily influenced by the university, NGO and philanthropic sectors (IAM 2014; Jackson 2017; Berman 1983), and the dominant vision and deployment of activism compartmentalizes political tensions and stifles the formation of recalcitrant political subjectivities (see Andrew X 2009 [1999]). Activism is a social label and conforms to institutionally directed theories of social change (Jackson 2017), and divisions of labor that reflect market society (see Andrew X 2009 [1999]; Goldman 2010). Conversely, in a university environment, it can isolate people from collaborating in rebellious spaces and conducting research to understand neglected or hidden realities. Activism, while understandably a useful term to indicate politically motivated activities, is applied narrowly and ambiguously, as it symbolizes only a limited and domesticated form of political engagement (e.g. petitions, mass demonstrations, canvassing and banner drops). To some, the relationships associated with activism can objectify struggles, proliferate categorizations, separate people through (self-important) informal hierarchies and undermine multifaceted struggle that transcends the political norms and relationships established by self-defined "activists" (Andrew X 2009; Anonymous 2003; Goldman 2010). Discussing these issues, Anonymous (2003) Author(s) explains activists:

...draft a rigid political program and work to recruit a membership that will adopt it. Activist organizations, both those structured with authoritarian leadership and those that make decisions democratically, demand that the individuals who make up their membership flatten their opinions and come to a lowest common denominator consensus.

Activism frequently limits individuals desires through bureaucratic procedures that-implicitly or explicitly-discourage other forms of political organization. Moreover, it implicitly compartmentalizes, denying the struggle for total liberation — humans and nonhumans - that Animal Liberation movements (Pellow 2014) and, now, anarchist political ecology are beginning to highlight (see Springer et al. in press; Brock 2020; Trainer, 2019a, 2019b). The "activist" label construction allows management, promoting an academic identity (with empowering and marginalizing effects): publisher marketing niche or ignoring research as "activist" (see Dunlap 2018c). "Activist research" can become marginalized in the academy, affirming this division between activist—or politically subjective—and so-called "objective" research. When in reality, all research is loaded with varying subjectivities and nearly all actions represent a form of activism laced prejudice and bias. Dominate socio-cultural values and powerful political positions, as we know, gain a objective status, when in reality they are far from it. We might relate the existing normative research assumptions, especially as they relate with the political economy of the university and industrial sectors, to ecological and climate crisis. In sum, the concept and relationship around activism — with its subtle rippling effects-deserves (re)consideration.

Finally, while the distinction between "revolution" and "insurrection" appears semantic or gets lost in the ambiguity of "resistance" and "social movements", it also widens the language of resistance. In 1844, the distinction between revolution and insurrection was famously made by Max Stirner (2017 [1844]: 301), who wrote:

The revolution aimed at new arrangements; the insurrection leads us to no longer let ourselves be arranged, but rather to arrange ourselves, and set no radiant hopes on 'institutions.' It is not a fight against the established, since, if it prospers, the established will collapse of itself; it is only a working of my way out of the established. If I leave the established, it is dead and falls into decay. Since now my aim is not the overthrow of the established order but my rising up above it.... The revolution commands one to make arrangements, the insurrection demands that one stand or rise himself up.

Insurrection rejects "new [governance] arrangements" that reproduce the "old" oppressions within the "new." While a bit hopeful that "the established will collapse of itself", insurrection has more philosophical depth than an uprising or a so-called riot, as it questions individual subjectivity, conduct and relationships to 
other humans, nonhumans and institutional arrangements. Revolutions, with all the various factions and desires that they comprise, have often intensified authoritarian and anti-ecological regimes. ${ }^{7}$ Recognizing the need for something "vastly different from the industrio-scientific" civilization we have now, Kirkpatrick Sale (2000 [1991]: 176) explains that: revolutions "almost never produce the contrariety but the continuation of what they have replaced." "The trouble with revolutions", Sale (2000: 176) contends, "is that by definition they go full circle and lead us back to where we came from." Insurrectionary anarchism-for the most part- does not entirely break with the concept of revolution (depending on the authors), yet emerges as a critical response to revolutionary methodology and practice to avoid circling back to forms of (anti-ecological) authoritarian rule and arrangements.

Insurrection, then, is the qualitative rejection taken by people to free or change their life from oppressive circumstances, actors or institutions. ${ }^{8}$ We can say that insurrection is the exertion of self-determination in its pure (individual or collective) political form. To "no longer let ourselves be arranged, but rather to arrange ourselves", means living fully by every means and it occurs on many levels and in many facets of everyday life (see Vaneigem 2012 [1967]). This is "multiscalar" in the jargon used by geographers. Fused with anarchistic values (e.g. direct action, mutual aid and voluntary association), authoritarian actors can label self-determining and unmediated activities as "subversive", "oppositional" and "anti-social", yet this is unsurprising. Anarchist conceptualizations of insurrection resonate with Indigenous articulations of resurgence that "advocates moving beyond a whole-scale revolution against the state towards creating relationships of autonomy, selfdetermination and independence" rooted in socio-cultural practices (Lewis 2017: 485). Insurrection, conceptually, acts against a totality of intersectional oppressions (see Loadenthal 2017: 171), implicitly challenging hierarchies and submission to political, economic and settler colonial regimes.

\section{Coming to daggers with Fukuoka}

Exploring the theme of insurrectionary anarchism, the well-known booklet At Daggers Drawn (Anonymous (2001 [1998]) offers a poetic political theory of organization and resistance. Masanobu Fukuoka's (2010 [1978]) One Straw Revolution introduces "do-nothing farming" or "no-till" gardening, which radically challenges common agricultural practices. Both tendencies represent sensitive, relational and —compared to the organizational political culture of techno-capitalist society - radical approaches challenging mainstream permaculture and classical anarchism. These two political and ecological tendencies, especially given historical and environmental contexts-remain experimental ideals to consider, adapt and discuss. The components of insurrectionary political ecology now follow, beginning with its ecological aspect.

\section{Rooting ecological praxis}

Who is Masanobu Fukuoka? While only few could really answer this question, the story told in The One Straw Revolution is that he was a Japanese biologist and bureaucrat working in the Yokohama Customs Bureau of Plant Inspection Division in 1938. Age twenty-five, Fukuoka had a lively personal and work life, making use of the laboratory facilities to study plants and fungi at the Customs Bureau alongside his regular work. Eventually, he hit his professional breaking point. "I believe it was this aimless life, coupled with fatigue from overwork, that finally led to fainting spells in the research room", he explains (2010: 7), resulting in acute pneumonia and hospitalization. Hospitalization led to severe loneliness and, once released, depression took hold. Exhausted, dazed and confused, Fukuoka collapsed under a tree on the hillside overlooking Yokohama harbor, only to wake up as "a night heron appeared, gave a sharp cry, and flew away in the distance." In "an instant all my doubts and the gloomy mist of my confusion vanished", explained Fukuoka (2010: 8). It was in that moment that Fukuoka "could see that all the concepts to which [he] had been clinging, the very notion of existence itself, were empty fabrications" (2010: 8). Fukuoka's relationship with nature went from microscope-

\footnotetext{
${ }^{7}$ Trainer's (2019a. 2019b) discussion of Marxism is helpful in drawing this out.

${ }^{8}$ Putting aside the embedded technophilia and stereotypes, I would argue the film Cloud Atlas (2012) depicts a series of "insurrections of everyday life" within various temporalities and political contexts.
} 
centered alienation to radical immersion, as he resigned the following day from his job. He then wandered the countryside until settling at his father's farm in Ehime Prefecture on Shikoku Island (Fukuoka 2012).

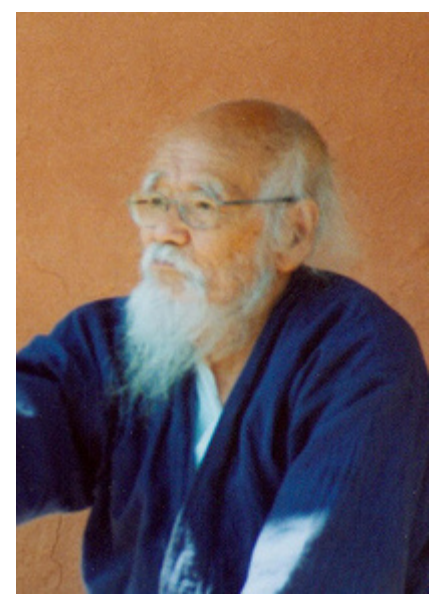

Figure 2: Masanobu Fukuoka. Source: Wikimedia Commons.

Building a hut on top of the hill, overlooking his land covered by tangerine orchards, Fukuoka "could only think of this concept of non-usefulness as being of great benefit to the world" (2010: 13). Fukuoka eventually undertook yearlong efforts to observe and experiment. Meanwhile, his father and most villagers were concerned about his mental health. Going in the opposite direction to common agricultural practices, Fukuoka rejected modern agriculture's obsession with chemical based fertilizers and pesticides branded as "improvements." Scattering "seed balls"— clay pellets containing various seeds_around the land was central to learning what mixture of plants would settle and flourish together in certain areas of the terrain. Through his experiences with the land, Fukuoka would come to advocate four principles of natural farming.

- First, "NO CULTIVATION" based on plowing and turning the soil: "The earth cultivates itself naturally by means of the penetration of plant roots and the activity of microorganisms, small animals, and earthworms" (Fukuoka 2010: 34).

- Second, "NO CHEMICAL FERTILIZERS OR PREPARED COMPOST." This is predicated on the idea that people's interference with nature disrupts natural cycles and prevents soil from healing: "If left to itself, the soil maintains its fertility naturally, in accordance with the orderly cycle of plant and animal life" (2010: 34).

- Third, "NO WEEDING BY TILLAGE OR HERBICIDES." Contrary to popular belief, weeds play an important role in building and supporting soil fertility: "Weeds should be controlled, not eliminated" ${ }^{9}$ by using mulch ground-covering plants like white clover or by temporary flooding (2010: 34).

- Fourth, "NO DEPENDENCE ON CHEMICALS." Diseased plants and insect imbalanced environments can be restored by natural means, through the observation of how different environments and plants support specific relationships.

Complications arise through the implementation of these strategies in site specific practices, as they depend on how well individuals can connect, listen, and learn to support various nonhumans. Developing this socio-

\footnotetext{
${ }^{9}$ Oddly, this echoes the biological metaphor of counterinsurgency that seeks social engineering as opposed to scorched
} earth tactics. 
ecological connection and ecological re-enchantment is what some might call a practice of decolonizing the mind and body.

The practice is slow, requires ecological knowledge of plants and remains context specific — just like any political struggle. There is an ethos of ecological collaboration and "working smart, not hard." When Fukuoka took over his father's farm, his "do-nothing" approach caused insect infestations and the death of plants and trees. "'What is the natural pattern?' was always in my mind", recalls Fukuoka (2010: 16): "In the process of arriving at the answer, I wiped out another 400 trees. Finally, I felt I could say with certainty: "This is the natural pattern."' This destructive learning curve is likely not an option for most people. Fukuoka (2012: 5) later reflects: "It was not farming; it was abandonment", but "at least I had learned from that disaster the difference between nonintervention and taking human responsibility."

In the process of learning the natural pattern, Fukuoka had to see how and what type of plants and tree species would grow and support each other, which entailed the death of various trees and plants. Fukuoka continues:

...to the extent that trees deviate from their natural form, pruning and insect extermination become necessary; to the extent that human society separates itself from a life close to nature, schooling becomes necessary. In nature, formal schooling has no function. (2010: 16)

Ivan Illich (2002/1970: 24) agrees: "The power of school thus to divide social reality has no boundaries." Beside seeing existing institutional ontologies and knowledge as counter-productive, intervention is acceptable to establish "the natural pattern." This pattern allows ecosystem flora and fauna to qualitatively thrive, which produces high qualities and quantities of food. Speaking to Fukuoka's institutional concerns, Vine Deloria Jr. (1999) recounts the agroecological knowledge of The Six Nations ${ }^{10}$, specifically the "Three Sisters" (beans, corn, squash) companion planting combination. "It was not until this century", explains Deloria (1999: 130), "when modern Western science discovered the nitrogen cycle, that anyone commented on the fact that, the Three Sisters provided a natural nitrogen cycle so that the fields were never worn out from farming." Indigenous traditional ecological knowledge (TEK) is instrumental to anti-authoritarian agroecologial practices, which Fukuoka's method expresses. A gardening method requiring sensitive and long-term knowledge of the environment, but at a certain point ${ }^{11}$ the only labor required is collecting food from a self-reinforcing edible ecosystem or forest garden.

Fukuoka offers a radical anti-authoritarian method of gardening. His method represents an individualistic articulation of Indigenous science, developing his "own system of knowledge" for ensuring "the flourishing of their communities' health, livelihood, vibrancy and self-determination" (Whyte et al. 2016: 25). A collectivist approach, while preferable, is not always available-entailing another set of challenges, if not barriers - and Fukuoka demonstrates his method for creating a flourishing human and non-human community within the socio-political circumstance of industrializing Japan. Fukuoka's method and permaculture in general serve as an important tool of not only ecological, but also Indigenous revitalization. While permaculture builds on Indigenous knowledge systems, Indigenous permaculture has developed the capacity to "connect people from traditional societies with practices endangered by legacies of oppression" (Fox 2009: 4). The Indigenous Permaculture organization started by Guillermo Vasquez links permaculture to specific Indigenous group gardening practices, promoting the construction of water catchments, grey water recycling, seed saving, composting and, overall, is conceived by Vasquez as "a way of cultural resistance" (Fox 2009: 2). Permaculture, as Juliana Fox (2009: 4) reminds us, connects "detailed Western scientific understanding to traditional agricultural practices developed through indigenous methods, and proven by the test of time." Fukuoka's methods are part of the Indigenous science and permaculture family (Hemenway 2009), which includes forest

\footnotetext{
${ }^{10}$ The Iroquois Confederacy of upper New York state and southeastern Canada, comprising Mohawk, Oneida, Onondaga, Cayuga, Seneca, and Tuscarora peoples.

${ }^{11}$ Constructing no-till natural farming ecosystems, according to a friend and permaculture expert who worked in Japan, Philippines and the US, takes roughly three years.
} 
gardening (Jacke 2005), urban permaculture (Fiebrig et al. 2013; Hemenway 2015) and radical versions of agroecology (Rosset and Altieri 2017). Fukuoka's tension with creating a radically anti-authoritarian, thriving and self-reinforcing ecosystems requires working "smart" and with nonhumans, not "hard" and against them to produce subsistence practices that require minimal work and little-to-no chemical inputs. I contend, while rooted in historical context, that this should remain an ecological ideal for insurrectionary political ecology.

Fukuoka's (2010) practice, however, is not without an embedded socio-cultural value system rooted in Taoism and Zen Buddhism (see also Fukuoka 2012). Fukuoka's "nature", importantly, describes the existent psychosocial separation, yet for him—and his desired relationships—does not exist separately. Nature — human and nonhuman-is changing and adapts—it is not static — but has differing qualities, vital strengths and relationships. Food is medicine, not a separate thing to Fukuoka. Deconstructing socio-ecological separation was central for him. Echoing similar concerns from the post-development school (see Illich 1969; Rahnema and Bawtree 1997), specifically around conceptions of poverty (Rahnema 1991), Fukuoka asserts, "extravagance of desire is the fundamental cause which has led the world into its present predicament. Fast rather than slow, more rather than less - this flashy 'development' is linked directly to society's impending collapse" (2010: 110). This manufacturing of extravagant desire also extends to diets: "Modern people have come to think that if they do not prepare food with elaborate seasonings, the meal will be tasteless", writes Fukuoka; "If you do not try to make food delicious, you will find that nature has made it so" (2010: 137). The "Western scientific diet" demanding "[h]igh quality beef, eggs, milk, vegetables, bread, and other foods" has "caused farmers to produce summer vegetables" in the winter, and is preventing people from eating within their environments and current seasons. Remembering Edward Bernay's (2005 [1928]) infamous public relations campaign to establish eggs and bacon as the defining "American" breakfast demonstrates how the industry has engineered structurally unhealthy dietary habits (see Newell 2009). "A natural person can achieve [the] right diet", Fukuoka contends, "because his instincts is in proper working order" (2010: 136). Living within the cycles and adjusting ones' pallet to their environment promotes good health and demands less extractive and transportation costs (see Dunlap and Jakobsen 2020), a far stretch from the current hyper-globalized urban environments many of us inhabit.

The role of the expert, and science and knowledge production in general are pressing barriers for Fukuoka. His Taoist beliefs shine when he contends that the "more involved they become with the activity of the intellect, the more they set themselves apart and the more difficult it becomes to live naturally" (2010: 154). This is an onto-epistemological challenge of the highest order for biologists, economists and social scientists. It is a direct intervention into the quantitative and algorithmic culture within which the modern political economy of data, university scholarship and the media operate. Fukuoka's immersion against scientism deserves respect - if not integration-it is one that Indigenous science has been working to articulate with the specific cosmologies, ontologies and practices of various Indigenous nations (see Whyte et al. 2016; Hatfield et al. 2018; Ulloa 2014, 2019). This recognition is particularly relevant to elaborating convivial conservation (Büscher and Fletcher 2020: 160), where conviviality_-"con(with) and 'vivire' (living)—means 'living with"' conservation. While socio-ecological separation as the root of ecological catastrophe has been re-affirmed recently (Moore 2015; Büscher and Fletcher 2020), Fukuoka—and Taoism—contend that "thinking" is separation. The alternative is immersion within natural habitats, developing a connection with ecosystems and feeling natural cycles or patterns, as opposed to measuring, dissecting and holding knowledge over nature. "Thinking", from this perspective, is the first act of separation: an act of self-ostracizing and separating ones' self from nature.

During Fukuoka's time as a state biologist, he was immersed into a culture of mechanical science. Yet he came to daggers with the scientific-"linear"-perspective that derived knowledge from separating, dissecting and extracting knowledge (see Dunlap 2014b). "Nature as grasped by scientific knowledge is a nature which has been destroyed; it is a ghost possessing a skeleton, but no soul", writes Fukuoka (2010: 125). Hence, when someone "thinks they are beginning to understand nature, they can be sure that they are on the wrong track" (Fukuoka 2010: 25). Ecological knowledge coming from immersion and observant participationbuilding nonhuman friendships-is an alternative pathway, emblematic of many rural and Indigenous cultures that Indigenous Science is activating. Discussing Indigenous science, Kyle Whyte and colleagues (2016: 30) confront sustainability science with the ontology that ecosystems are "full of relatives not resources", asserting 
that Indigenous science measure wealth "not by resource ownership and control, but by the number of good relationships we maintain in the complex and diverse life-systems of this blue green planet" (see also Ulloa 2014, 2019). The dominance of modern mechanical science and its way of relating to nature is relatively new and, as ecofeminists have long documented (Merchant 1983; Shiva 2002; Federici 2009 [2004]), was engineered through bloodshed and extermination across the world (see Mignolo 2005; Mbembe 2009). Recognizing the resulting loss of (land-based) knowledge — among other "historical contents"— Foucault demanded an "insurrection of subjugated knowledges" (2003: 7), which Fukuoka began through force of societal circumstance and bodily breakdown. Social resilience, then, flourishes through the qualities of relationships based on reciprocity and respect, as Kyle Whyte $(2018: 139,140)$ points out. This is why "climatic vulnerability" undermines "Indigenous qualities" with the pollution/emissions by many industrial activities whose operation are/were secured through colonial land dispossession/shrinkage.

\section{Rooting political praxis}

Fukuoka's revulsion about control and his nurturing of anti-authoritarian ecosystems resonate profoundly with insurrectionary anarchist tendencies. Insurrectionary anarchism is an experimental and relational praxis. It not only challenges Leftist political parties and organizations, but also anarchism itself, by questioning assembly organizational forms, and anarcho-syndicalism's workerism and attachment to factories (Bonanno 1998b [1996]), which even extends to recognizing the authoritarian shortcomings of consensus models (Passamani 2014; see also Trainer, 2019b). Anarchism is recognized as a tension ${ }^{12}$ (Bonanno 1998b), that is practiced and channeled through people and the repressive situations they confront. While the values enacted by insurrectionary anarchism, are simply anarchist, there is a distinct challenge to classical anarchist tendencies (see Bonanno 1998b, 2013). Anarchists reject hierarchy, inequality and the logic of submission imbued and necessitated by industrial society (see Landstreicher 2009). Informal organization or dis/organization challenges the traditional, arguably "colonial" (Dunlap 2018b), and statist forms of organizing that have come to dominate the last two centuries (see also Gelderloos 2017). Central to informal organizing is the concept of affinity. "Relations of affinity do not exist on the basis of ideology or quantity, but start off from reciprocal knowledge, from feeling and sharing projectual passions", explains the Author(s) (Anonymous 2001: 15). Small groups of people, friends more-or-less, organize based on shared interests, political analysis, and life tensions among other countless other things (see López 2014).

We can locate the organizational principles and values of insurrectionary anarchism in earlier formations within the history of nomadic and semi-nomadic peoples, and Indigenous warfare and social banditry, which employ strategies, tactics and lifeways of autonomous struggle and ecological defense (Dunlap 2018b; Gelderloos 2017; Virilio 1990). While insurrectionary anarchism has ancient non-European precedents (Dunlap 2018b), it more immediately builds from Kropotkin and Bakunin's anarcho-communist emphasis on collective struggle and controlling productive infrastructures to institute egalitarian, self-organized and peasant-led movements (see also Roman-Alcalá 2020). Meanwhile taking up Stirner's iconoclastic insurrectionary proposal along with the legacy of Illegalists, ${ }^{13}$ Renzo Novatore and Luigi Galleani focused on free-will, individual and direct action. This also includes a rejection of workerism, the political theory that emphasizes, if not glorifies, the working class and its morality. Formalizing an idea and practice arising from 1970s revolutionary Italy (see Weir 1990 [1979]), insurrectionary anarchism began to take shape with Alfredo Bonanno's (1998a [1977]) influential text, Armed Joy. At the time of its publication, it was banned and copies were burned, and Bonnano was sentenced to eighteen months in prison for authoring the text. Apparently, the text's proposed paradigm shift for militant struggle threatened the Italian state. Anarchism, then, is defined as a tension. "Anarchism is

\footnotetext{
12 "Anarchism is not a concept that can be locked up in a word like a gravestone. It is not a political theory. It is a way of conceiving life, and life, young or old as we may be, old people or children, is not something definitive: it is a stake we must play day after day. When we wake up in the morning and put our feet on the ground we must have a good reason for getting up, if we don't it makes no difference whether we are anarchists or not. We might as well stay in bed and sleep" (Bonanno 1998b: 4).

${ }^{13}$ Related to the Bonnet Gang, Johann Most, Luigi Galleani, Victor Serge and Severino Di Giovanni, Illegalism refers to anarchists that embrace crime as a lifestyle and the idea of "propaganda by the deed."
} 
not a concept that can be locked up in a word like a gravestone. It is not a political theory. It is a way of conceiving life" (Bonanno 1998b [1996]: 4), "young or old as we may be, old people or children, it is not something definitive: it is a stake we must play day after day" (Figure 2).

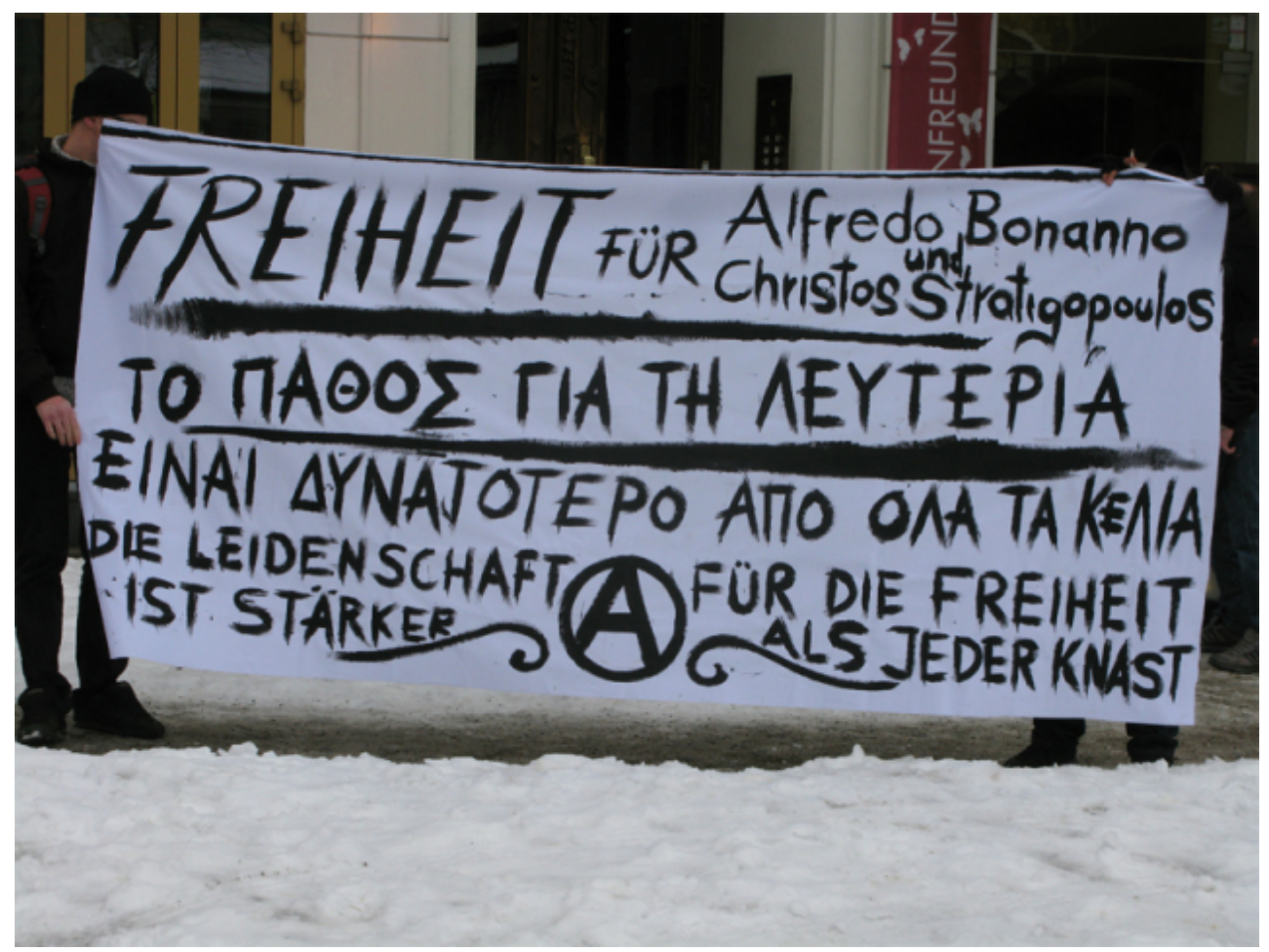

Figure 3. "Freedom for Alfredo Bonanno \& Christos Stratigopoulous. The passion for freedom is stronger than any prison." Both arrested for bank robbery in Greece, Bonanno was age 73 in 2010. Source: Wikimedia Commons.

Armed Joy offered an intimate criticism of Leftist armed struggle and organization, specifically of the Red Brigades or groups like The Red Army Faction (RAF). The book rejected "the soldier" and the culture of militancy, reflecting on the organizational-and consequently socio-cultural—failures of "traditional revolutionary organization" that creates armed specialists, separates militants from the larger population and fails to challenge the "whole apparatus of the western cultural tradition[that] is a death machine" (Bonanno, 1998a: 41). "In order to break out of the magic circle of the theatricals of commodities", Bonanno (1998a: 37) contends, "we must refuse all roles, including that of the 'professional' revolutionary" (emphasis added). Bonanno did not deny armed struggle, illegalism or direct action. On the contrary, he offered a self-reflective analysis to advance anti-authoritarian struggle by joining means and ends with non-hierarchical and antioppressive organizational forms that, most importantly, were effective and self-sustaining in the face of systematic state repression. Central to his argument was a need to change the culture and root of militant struggle from subservient rank-and-file (party) hierarchies, moralistic asceticism and militarism —resembling Christian ontology ${ }^{14}$ — in order to struggle from a place of "joy", "play" and "love." "[A]nyone who loves life does not embrace their exploiter", says Bonanno (1998a): "To do so would signify that they are against life in favour of sacrifice, self-punishment, work and death." Rooting struggle in joy and love, means emphasizing qualitative dimensions of relationships and struggles, connecting means and ends and rejecting the quantitative logic of

14 See also Aragorn! (2015), who notes how the term "Revolution" repackages Christian rapture and mimics a familiar ontology. 
the economy, political parties, unions and their monopolistic armed wings. A different (qualitative) logic, relationship and method of struggle is what would undermine capitalism and the society of the spectacle. Armed Joy is one of the few texts that critically reflects on the failures of revolutionary armed struggle, refusing a slide into bureaucratic politics and pacifism. Instead, it sought to strengthen "revolutionary" anarchist struggle.

Informal organization is affinity-based, small scale, and it is a form of self-organization that rejects political mediation (e.g. unions, political parties, institutions). It implements a self-determined permanent conflict with an existing target (e.g. institution, company, development project) marked by "attacks"—-taking (thoughtful and) immediate direct action (see Sasha K 2001). Jean Weir summarizes the position:

We have always said that small actions, small attacks, even made by one or two comrades, are very valuable. And this goes beyond being part of a specific struggle: we can attack all the time, because we are under attack all the time. And these actions are realised by affinity groups, and they might have a certain opening, but they are also a proposal, a theoretical proposition, that we can attack and we don't need to be a hundred thousand. (Weir et al. 2015: 33)

Importantly, organization is temporary, existing only until a defined objective is achieved. Informal organization promotes radical decentralization, people organizing themselves autonomously—as individuals or collectives - based on a shared value system or objective, reflecting a multiplicity of unique circumstances. ${ }^{15}$ Once an objective is achieved, people dissolve and reconfigure to avoid bureaucratization and relational stagnation. As Carlos "Chivo" López summarized: "that which stagnates rots." Unions, political parties and NGOs give life to organizations that require infrastructure, personnel and institutional formations, which are regarded as a form of political "self-compositing" or neutralization: mediating and separating people from direct engagement in human and nonhuman natures. Insurrectionary anarchism is a praxis operating on multiple scales and emphasizing the quality of relationships and actions (as opposed to quantity). Assemblies and direct democratic methods have been, and continue to be, a part of larger organizational methods (see Bonanno 1998b), which is not without critical reflection (see Anonymous 2011; Rodriquez 2014; Weir et al. 2015). Informal organization is a conscious reaction to both the "hard" and "soft" repression of the corporate state, but also the replication of statist structures and market dynamics within groups or on the micro- and meso-scale. People's political positionalities, lived realities and environments might make this level of antagonism and organizational challenge seem "impossible", yet this is a method of struggle circulating with great frequency around the world (see Green Anarchy 2012; Return Fire 2013; Black Seed 2014; Loadenthal 2017), even if the numbers are not quantifiable (being unknown and shifting). Insurrectionary anarchism is an experimental political praxis, offering insights into organizational shortcomings and proposing ways to act for freedom now and to undermine socio-ecological catastrophe.

This political praxis is by no means perfect, yet it locates and challenges the roots of socio-ecological catastrophe: the political economy. "[A]nyone who is incapable of imagining a community without State Authority is devoid of instruments with which to criticize the economy that is destroying the planet", Anonymous (2001: 15) Author(s) explain. Peoples' positionalities, priorities and politics demand reassessment in the face of planetary destruction and amidst preparations for terraforming and mining other planets. Likewise, questioning institutional cores, the prevailing models of organization and social movement dynamics remains central. "The 'social movement' thus becomes the justification for the party (which in the Leninist version becomes an elite of professionals of the revolution)", explains Anonymous (2001: 24) Author(s). Simultaneously, "With the pretext of not separating oneself from the 'social movement', one ends up denouncing any practice of attack as a 'fight forward' or mere 'armed propaganda'." This is to say, social movements can create vertical bureaucratized hierarchies by separating people into managerial roles, while also denouncing action from people who are not following (an ambiguous) party line or morality, thus replicating the issues of scale and separation associated with state governments.

15 See Weir et al. (2015) for an example of a struggle against the construction of a Maximum Security Prison in Belgium, highlighting the successes, but also the impasse of an ongoing struggle. 
In contrast the insurrectionary emphasis on "diversity of tactics" - or "companion planting"16 of actions - encourages a pluriverse of subjectivities and actions (see Gelderloos 2013). Raul Zibech's "societiesin-movement" recognizes a multiplicity of diverse and rhizomic tendencies in regional or national social upheavals (2012: 208). This refers to the spread of multiple — and often contradictory- actions, methods, people and informal assemblies to decide their actions or "social consensus." Massimo Passami (2014: 45) describes how social consensus - in the formal sense - is a "force, and its imposition is exercised through precise structures", serving a purpose of "preventative repression, policing of ideas and decision." ${ }^{17}$ These are sensitive organizational dynamics, little discussed in political ecology, as there is a natural separation from political struggle in academic practice. This can take on increasing — and debated-complications of "nonindigenous" anarchists struggling in Indigenous lands (Lewis 2017; Anonymous 2018b). Moreover, for academics and scholars, the organization of universities, departmental (bureaucratic) politics, the politics of publish-or-perish pressures and negative attitudes towards "activism" already structure organizational hegemony, dependency and, consequently, habituated blinders to re-conceptualizing organization, let alone struggle. It is time to put organization and method back on the chopping block to widen conversations and promote a diversity of visions and practices.

\section{Dancing with insurrectionary gardening}

Important, here, is locating common ontological foundations between insurrectionary anarchism and Fukuoka's "do nothing farming", in order to understand the roots of insurrectionary political ecology. John Clark demonstrates affinity between Zen Buddhism and anarchism (2019: 193-205). The epigraphs that I quoted the start of this article juxtapose Zen Buddist Linji and Alfrendo Bonanno's rants and are expressions, in Clark's words, of an "attack on sick attachments and abstract idealist views of reality." (2019: 196). Both reject the making of specters or phantasms out of spiritual or political leaders (see Stirner 2017), transforming their words into dogma (or law). There "are no ideas, beliefs, propositions, or supposed objects of knowledge", explains Clark (2020: 196), "that can be accepted dogmatically, ideologically, or as abstract universals having any reality beyond the limits of experience." This demonstrates how Zen Buddhist has a line of affinity with insurrectionary anarchism. This affinity extends, according to Clark (2019: 202), with everything being a practice in Buddism. Fukuoka and insurrectionary anarchism, while not only embodying anti-authoritarian tendencies, might also share some ontological underpinnings in the way it approaches the world. Obviously, the former takes an explicitly combative approach.

Control emerges as Fukuoka's and insurrectionary anarchism's common target, resolutely positioning both tendencies as anti-authoritarian. Both reject the regimentation and poisoning of habitats, their difference lies mostly in political attention and ecological emphasis. Fukuoka emphasizes the creation of anti-authoritarian ecosystems, while anarchists focus on organizational relations to attack various structures of domination. Both have identified and reject in theory and practice a political ecology of domestication. The methods they articulate are complementary, and both commit political and ecological "disturbances." Disturbance "refers to an open-ended range of unsettling phenomena", explains Anne Tsing (2015: 160), which come to humans and nonhumans in the form of floods, fires, sabotage, riots and societies in movement. Fukuoka enriches his immediate environment, while organizing anti-authoritarian food autonomy with his farm and spreading the vision of no-till natural farming. Anarchists, on the other hand, tend towards dedicating their time to the deconstruction of institutions of oppression, while organizing a political ecology of disturbance. Obviously there are exceptions (see Trainer, 2019a, 2019b), yet insurrectionary political ecology complements and challenges "scholar-activist" schools of thought, such as decolonial degrowth, environmental justice, postdevelopment and convivial conservation. These schools draw on social movement theory, (autonomous) Marxism and Indigenous social movements, neglecting —at least in academia—the anarchist influence and

\footnotetext{
${ }^{16}$ Companion planting refers to the planting of different crops close to each other for various reasons: pest control, pollination, providing habitat for beneficial insects, maximizing use of space and so on.

${ }^{17}$ For more on the topic, read TIC's (2017) Now. The TIC's Now drops its subtle anti-anarchist stance in earlier works, while offering an impressive discussion on assembly relations in the Nuit Debout occupations of Paris in 2016 that have a wider application.
} 
critical praxis within them. ${ }^{18}$ Moreover, hostile anarchist organizational forms and Fukuoka's method of agroecology offer substance and experience to draw from. Insurrectionary anarchists would benefit from Fukuoka's practices, and vice-versa, if only in recognizing the self-reinforcing connection between vibrant environments (and food) and land defense.

The social organization and infrastructure of environments are central concerns to Fukuoka and insurrectionary anarchists. Fukuoka and insurrectionary anarchist texts like At Daggers Drawn (Anonymous 2001) identify government policies and institutions as structural problems to living ecologically sound or liberated lives, thereby rejecting the delusions of industrial society. Fukuoka (2010: 83) identifies the chain of blame in this order: "the farmer who applies polluting chemicals to his field, the corporations who manufacture these chemicals, the village officials who believe in the convenience of chemicals." Meanwhile, anarchists emphasize the way statist social organization resembles a prison-"prison society" (Stirner 2017: 204-205; Return Fire 2013: 1; Weir 2017)—or military barracks: "Children's play areas with the cement of the car parks, banks and shopping centres? The empty houses left in the hands of the speculators? The blocks of flats that look like army barracks, that look like schools, that look like hospitals, that look like asylums?" (Anonymous 2001: 7-8; see also Dunlap 2014b). Both are concerned about the organization of space and the relationships embedded in space. The Anonymous (2001: 8) Author(s) contend: "Anything that has been designed for economic or religious purposes cannot fail to impose anything but economic or religious desires." This truism summarizes findings that infrastructures are imbued with particular socio-cultural value system and orders (Dalakoglou 2017; Dunlap 2020b), and are not simply "non-places" (Augé 2008 [1995]). Anarchist's and Fukuoka's insurrectionary political ecology are disturbances to techno-capitalism, while (urban and rural) planning bodies, repressive institutions and their malfunctioning socio-ecological values are anti-ecological disturbance suppressants designed to continue production, consumption and dependency. We might conceptualize "social development"-in the developmentalist counterinsurgency sense—as a chemical fertilizer employing "soft" and "hard" practices of coercion (see Dunlap 2020a) like pesticides and herbicides, to maintain and expand the techno-capitalist plantation. The "farmer who tries to control weeds by cultivating the soil", Fukuoka reminds us, "is, quite literally, sowing the seeds of his own misfortune" (2010: 84). The imposition of techno-industrial society by every coercive and psychological means is quite literally sowing the seeds of permanent war against (human and nonhuman) nature. This "war" is an existent reality for many, but especially Indigenous groups engaged in anti-colonial struggle, that perceive the (neo)colonial state as an occupational force (Ramnath 2011: 32). Experimentation with appropriating infrastructures, and what exactly constitutes a decolonial and non-state infrastructure, deserve greater consideration and debate. Fukuoka offers an ecological avenue for creation —alongside permaculture, "guerilla gardening" and green building (Evans et al. 2002; Hemenway 2009, 2015; Trainer 2019a, 2019b)—while insurrectionary anarchists emphasize programless anti-authoritarian forms of self-organization based in joy and unmediated political actions.

Furthermore, the quality, and not quantity, of social relationships are central to both Fukuoka and insurrectionary anarchists. "No matter how the harvest will turn out, whether or not there will be enough food to eat", explains Fukuoka (2010: 114), "in simply sowing seed and caring tenderly for plants under nature's guidance there is joy." This certainly deserves caution given the hardships of cultivation (see Flachs and Richards 2018), yet Fukuoka (2012) emphasizes the need to revitalize connection and joy by participating within ecosystems. Development industries, harsh environmental conditions and failed farming practices have led to exit them or destroy them. Taking joy in praxis underpins both Fukuoka and insurrectionary anarchism, the first emphasizing re-connection and the spread of eco-systemic vitality, the second refusing to be a victim to techno-capitalist society and takes pleasure in organizing direct action. Related to the organizational criticism of Armed Joy which rejects the "armed specialist" and divisions of labor built on expertise-a criticism also voiced by Ivan Illich $(1977,1978)$-Fukuoka $(2010: 22)$ loathes the specialist: "the world has become so specialized that it has become impossible for people to grasp anything in its entirety." Fukuoka (2010: 23, 25,

${ }^{18}$ The Zapatistas are increasingly in contact with, and integrating, anarchist critique into their autonomous project, combining Mayan culture with autonomous Marxism and anarchism. The convergences in 2015 seminar held in San Cristóbal de Las Casa, Chiapas, titled Critical thought in the face of the capitalist Hydra serves as one of many examples of this anarchist-autonomists convergence 
36) reiterates the way specialists fail to see holistically the various processes within ecosystems and prevents people from addressing "the problem at its fundamental level." While specialized knowledge remains helpful (see Jacke 2005), and the rise of Indigenous science is promising (Whyte et al. 2016; Ulloa 2014, 2019), many biological and ecological specialists will not challenge their own knowledge and their jobs. Moreover, the relationship created by (extreme) specialization will render people dependent on techno-capitalist systems, which have failed for centuries to create socio-ecological harmony.

Criticisms of specialization go hand-in-hand with criticisms of science, technology, industrial progress and work. As mentioned, Fukuoka turned his back on (modern) science as a limited way for understanding ecosystems and human health. Insurrectionary anarchists, more so than classical anarchists, retain a healthy skepticism of science and technology (see Green Anarchy 2012; Gorrion 2015; Anonymous 2018a), but to a lesser degree than Fukuoka's Taoist approach (see Fukuoka 2012), yet criticisms and/or rejections of epistemic dominance is group or individual specific. Anarchists are appalled at the lack of critical engagement with the political orders emanating from the management of scientific knowledge more than the scientific method itself. The problem of scientism becomes more distinct in matters of technological development. "Criticizing technology means considering its general framework, seeing it not simply as an assemblage of machinery, but as a social relation, a system", explains the Author(s) (2001: 18), "it means understanding that a technological instrument reflects the society that produces it and that its introduction changes relations between individuals. Criticizing technology means refusing to subordinate human activity to profit." Various insurrectionary and green anarchist positions take a harder stance on technological development and science (Zerzan 1989; Green Anarchy 2012; Anonymous 2018a; Return Fire 2013; Black Seed 2014), often advocating for primitive (Zerzan 2012), convivial and appropriate technologies (see Illich 1973; Schumacher 1973). Fukuoka and insurrectionary anarchists are resolutely against separating from nature in theory, even if this can be more complicated in practice.

Fukuoka's whole philosophy is about working smart, not hard, and with nature, dedicating his life to restoring ecosystems from a place of joy. The popular title, Let's destroy work, let's destroy the economy (Bonanno 2013 [1995]) demonstrates the insurrectionary anarchist antagonism towards work, which is not always a position shared by anarcho-syndicalists (see also Black 1986). Work reproduces capitalism, serving as a psychosocial pacifying mechanism alongside the comforts-and ecologically costly-fruits of technological society. Feminist post-work politics acknowledges how "work" is instrumental to disciplining subjectivities, affirming political conventions and ecological catastrophe (see Daggett 2019). "The normality of work and 'time off', the family and consumerism, kills every evil passion for freedom", writes the Author(s) (2001: 22, 8): "Work reproduces the social environment which reproduces the resignation to work. One enjoys evenings in front of the TV because one has spent the day in the office and the underground. Keeping quiet in the factory makes shouting in the stadia a promise of happiness." The organization of society around work and consumption produces severe socio-ecological costs, effecting rich and poor with variegated material and psychosocial poverties. Poverties that can be remedied by political ecology practices of "revolt (not therapy)" (Wolfi 2009b: 123) and natural farming. Ted Trainer (2019a, 2019b) offers a more practical approach through his practices and analysis of "The Simpler Way" that offers a small-scale program of degrowth organized around permaculture and anarchist methods. The detail, and applied legwork in advocating decentralized and ecologically sustainable organization of suburban space remains an important reference and resource.

Finally, consistent with anarchist criticisms of "activism" above, Fukuoka and anarchists criticize "single-issues." Fukuoka demands an immersed and more holistic view. Using pollution as an example, he explains: "To talk about cleaning up specific cases of pollution is like treating symptoms of a disease while the root cause of the malady continues to fester" (2010: 79). Anarchists, following animal liberationists, advocate for total liberation (Loadenthal 2017: 171; Springer et al. in press): oppressive relationships and domination form total or "ultimate intersectionality." This relates to Indigenous struggles against settler colonialism. Total liberation must also recognize the necessity of Indigenous self-determination. Highlighting anarchist neglect of settler colonialism, Adam Lewis (2017: 474-476) argues that "[r]adical futures, to be decolonial, must be on Indigenous terms" indicating that anarchists must become "directly accountable to Indigenous laws and political systems." [While the historical genocidal-ecocidal recognition is a necessity, along with recognizing Protocols (see Whyte et al. 2016), there remains an important critical space for recognition. There are differences between 
visions of Indigenous intellectuals, Indigenous cosmologies and traditions resurging and (variegated) tribal governance systems internalizing and re-projecting statist (neo)colonial relations (see Dunlap 2020c). The recognition and respect for Indigenous sovereignty, cosmologies and traditions, can be different from submitting to colonial-statist governance schemes perpetrating (multiple and various degrees of genocidal) assimilation and ecocide (Dunlap 2020d). This asserts, following a Michif-Cree (Anonymous 2018b: 5, 14), that "your politics matter" because:

...saying you support Indigenous sovereignty doesn't mean backing every Indigenous person on every project. There are plenty of Indigenous misogynists, and ladder-climbing politicians out there, and you don't do me any favours by helping them gain power. Fight for liberatory ideas, not for nations or bloodlines.

Governance systems, their politics and their relationship with the land and ecosystems demand realistic and respectful engagement within Indigenous territories. The aim is total liberation, which can only done by ourselves and with each other, not for people. This depends entirely on where one lives, the relationships they negotiate and choose to create (see also Trainer, 2019b). This approach opens the timeless issue of organization. The following section will review anti-authoritarian organizational theories in hopes of further discussion and elaboration within insurrectionary political ecology.

\section{Insurrectionary habitats everywhere}

How does one employ insurrectionary political ecology in daily life or in academic research? The quick answer is that it depends entirely on the individuals, affinity groups or communities that people co-habitat with. There is no unique prescription. There is only integrating these tensions into one's life: the identification of socio-ecological problems (hierarchical social relations, ecological separation, entrenched divisions of labor, workerism, etc.); an ecological philosophy cultivating enriched anti-authoritarian nonhuman relationships and gardening practices; as well as a method of self-organization that challenges existing relational models, evades control and enacts a philosophy of direct action. People's individualities, circumstances, environments and imaginations determine the limit of their political project.

The "natural pattern", described by Fukuoka, offers a point of caution. While Fukuoka had been immensely successful in immersing himself into his habitat, shaping anti-authoritarian ecological relationships and building a healthy and highly productive environment, any claim to a "natural pattern" risks creating an authoritarian universal truth that, to say the least, deserves skepticism. Conversely, ecological rehabilitation and restoration will take many pathways, entrenched in specific socio-ecological contexts (Trainer, 2019b). That being said, Fukuoka's guiding principles—reinforced by forest gardening and radical permaculture (see Jacke 2005; Hemingway 2009, 2012) - exhibit beneficial directions to cultivate ecological values and relationships. We might define our criteria as those natural patterns that enrich human lifeways and their relationships to nonhumans, promoting free and resilient anti-authoritarian self-organizations that minimize the need for formal and informal governance, on which neoliberal political economy thrives.

Insurrectionary political ecology, or the one advocated here, locates a general ideal — a pathway, direction or compass - that reveals itself as a sensitive and vulnerable socio-ecological practice. Like insurrectionary anarchism-with its various tendencies, practices and criticisms-insurrectionary political ecology is a prod for experimental research to promote anti-capitalist and anti-authoritarian (human and nonhuman) ecosystems. Given the onset of climate catastrophe, following Stephanie Wakefield, we can conceptualize these socio-ecological crises as opportunities to decide "for ourselves, locally and in diverse ways, where and how" (2017: 9) to inhabit these crises, making resilience programs opportunities for making social change and taking pleasure in the process. This perspective stresses "grass roots" immersion, connection and joy over productivity, efficiency and output. It challenges the ethos of capitalism, academic production and our disciplinary process within industrial society in general. The question of organization, however, remains timeless. Below I will review anti-authoritarian methods of organization to debate and expand individualcommunal initiatives, but also to enrich debate within political ecology. 
The problem of organization: counter-hegemony versus viral subversion?

Organizing anti-authoritarian political struggles and ecological lifeways remains central to insurrectionary political ecology. The organizational debate is old, operates on many scales and has resurfaced in academic human geography between Simon Springer (2014, 2017) and David Harvey (2017), where the former challenges Marxist vanguardism ${ }^{19}$ and authority within the discipline of geography. Insurrectionary political ecology takes this debate further in order to explore other possibilities, while critically examining the organizational ideas of "counter-hegemony", counter-institutions or "duel-power." Fukuoka and insurrectionary anarchism focus on social and ecological configurations - or organization — that prevent authoritarian control and (progressively) degrading ecosystems. One organizational analogy employed to discuss action group dynamics is the "knife" and "virus" (Anonymous 2011). "[T]he best thing for power is a clearly recognizable and definable knife which tries to stab a piece of it", explain the Anonymous (2011: 3) Author(s), "while the worst for power is a virus that risks harming the whole body in an intangible and therefore uncontrollable way." The idea is to create evasive defenses and attacks capable of defending lifeways, each other and their habitats, without a seemingly fixed place or infrastructure. Political ecology recognizes the state, and its political economy, is "fundamentally at odds with genuine desires for ecosystem protection" (Mullenite 2016: 382), leading insurrectionary political ecology to nurture anti-authoritarian political organization through affinities (see Trainer, 2019b), what we can call "viral subversion", to restore socio-ecological health. The employment of the term "virus" implies an evasive, self-replicating and contagious force, a tension or lifeform whose evolution and movements challenge attempts at legibility and control.

Viral subversion does not carry any flag, proclaim any territory or make claims of separation. Instead, subversion is a lived, subtle and continuous practice that creates unmediated socio-ecological relationships to restore ecosystems through free political practices. Through everyday socio-ecological actions, small attacks, one can work towards creating realities and environments that embody the socio-ecological values of insurrectionary ecology. Struggle everywhere - and immediately - to create spaces of unmediated political activity and exploration. This informal organizational trajectory is historically supported by Paul Virilio's (1990) review of popular ecological self-defense, James Scott's documentation of evasive forest gardening (2009), crooked military theorists (Boot 2013), and experiences of Indigenous and anti-colonial warfare (Gelderloos 2017; Dunlap 2018b). There are no "rules" or "pure" ways to do this, just anti-authoritarian socioecological values to guide relationships and insurrectionary organizing to develop pathways outside and against techno-capitalism. Thinking of Ethan Hughes, people should "take a risk where ever you are at", one-step at a time to slowly move in the direction of their own socio-ecological insurrection (see also Lockyer, 2017; Trainer, 2019b). ${ }^{20}$ Viral subversion, in reality, is not a virus but an antidote — a medicine - that takes on positive viral qualities in the face of techno-capital progress.

Viral subversion creates a pathway to think with and through notions of "counter-power" that are predominant in academia. Autonomous Marxism, from squat networks to autonomous territories, exemplify the most complementary versions of radically democratic counter-institutions. George Katsiaficas's documentation of "the (anti)politics of autonomy" in order to resist the "colonization of everyday life" in Europe (2006 [1997]) and John Holloway's (2010: 11) theory of immediacy of action both reject state power and seek to break capitalism "in as many ways as we can" to "expand and multiply the cracks and promote their confluence.". Predictably, Harvey (2017: 247) "disagree[s]" with Holloway's view of radical decentralization (see Springer 2017). Holloway's idea of a "multiplicity of interstitial movements running from the particular" arising from an "anti-politics of dignity" in "mutual recognition of persons" and resonates with insurrectionary political ecology (Holloway 2010: 39). He draws from his long residency in Mexico and his engagement with the experiences of the Zapatistas.

Similar to Katsiaficas and Holloway, The Invisible Committee (TIC 2009 [2007]: 42) presents an insurrectionary proposal to widen Holloway's cracks in capitalism, based on the development of a network of anti-state communes. "[A] multiplicity of communes that will displace the institutions of society: family, school,

\footnotetext{
${ }^{19}$ Vanguardism is a hierarchical strategy and organization of the most class-conscious and politically advanced to guide the revolution or "revolutionary" state.

${ }^{20}$ See Mann and Hughes (2015), at 15:20 min.
} 
union, sports club, etc.", explain TIC (2009: 102). The Invisible Committee's (TIC 2009 [2007]: 42) proposal for developing a network of anti-state communes is based on affinity, and represents an important organizational proposal, even if lacking an (explicit) ecological practice as well as critiques of divisions of labor and patriarchy. ${ }^{21}$

The earlier bioregionalism vision offers a similar program. Through working at the meso-scale, as opposed to the TIC's micro-scale commune proposal, Kirkpatrick Sale (2000 [1991]: 94) contends:

The primary location of decision-making, therefore, and of political and economic control, should be the community, the more-or-less intimate grouping either at the close-knit village scale of 1,000 people or so, or probably more often at the extended community scale of 5,000 to 10,000 so often found as the fundamental political unit whether formal or informal.

Promoting food, energy, economic and regional autonomy, bioregionalism promotes a society based on ecologically oriented Libertarian Municipalism. Bookchin (1991: 83) describes Libertarian Municipalism's "duel-power" goal as trying "to establish or restore town meetings, neighborhood assemblies, or even neighborhood councils of active citizens as the foundation of local control." Municipalities become the central site of organizing community control, which Bookchin (1991) said is done through neighborhood assemblies, engagement with electoral politics and grassroots mobilization. TIC's (2009) Commune and Bookchin's (1991: 83) Libertarian Municipalism share organizational parallels. Bookchin (1991: 83) advocated for "unofficial citizen assemblies" to "establish a 'shadow' or 'parallel' city council that is made up of elected and recallable delegates from each neighborhood assembly." On this, TIC (2009: 113), notably, reflects on the dangers of creating combative visibility that will attract repression. Yet, TIC offers a similar proposal, built around communes and containing a more antagonistic political practice. Critically, Libertarian Municipalism, along with bioregionalism, represents a less racist and more ecologically conscious rebranding of Jeffersonian democracy. Trainer's (2019b: 220) development of the "Simpler Way" is a noticeable complementary and practical advancement of Bookchin's Libertarian Municipalism, which confronts the issues of formal "counterpower" with "informal discussions", "spontaneous actions" to deal with practical issues and "town assemblies enabling thoroughly participatory democracy." Libertarian Municipal bioregionalism is a practical, direct democratic program with political prescription that is currently being developed by revolutionary Kurds in Rojava (see Dirik et al. 2016). "Duel power" or "counter-institutions", arguably, reproduce reformed versions of the existing structures of control. TIC (2009, 2015), more than Bookchin, are proposing advancements in confronting the development of counter-bureaucracies, yet they are still recommending organizing counterpower. A question for debate arises: once successful, will they dissolve power and create unmediated spaces, or will the bureaucracies and old power relationships reconstitute themselves? Informal —or self-appointed— commune leaders are likely to accumulate power and negotiate with dominant political authorities. Holloway's (2010: 6) recognition of political "continuity" between a myriad of everyday actions, is preferable to recuperating upheaval and riots across the world into a "historical party" (TIC 2015: 16) or "Imaginary Party" (2011 [1999]). ${ }^{22}$ This language echoes a bureaucratic vanguardism long criticized by the insurrectionary anarchist tendency (see Landstreicher 2011; Anonymous 2016). Although there is common ground between autonomous Marxism and (insurrectionary) anarchism, the former seeks to dispense power as opposed to accumulating it into political structures. Insurrectionary anarchism rejects the erection of bureaucracies with (informal or formal) political candidates, and the reproduction of political structures that mimic the existing colonial/statist organizational structures. In the Zone to Defend (ZAD) struggle against the airport in NotreDame-des-Landes in France (Figure 4), there were ontological disagreements over political structures and collaboration with state officials (see Crimethinc 2019). These produced discord, relational failures and impasses that demanded critical self-reflection. Counter-institutions like these movements tend towards

${ }^{21}$ As compared to green anarchism, see Green Anarchy magazine (2005) and Return Fire (2013), specifically 2014 Volume 2 of Return Fire.

${ }^{22}$ This refers to anarchists criticism of the rebranding of the (communist vanguard) "Party" by the TIC with the nuanced "Imaginary Party." 
hierarchical dynamics that risk extending the bureaucracy of everyday life. This is not to deny the success of a multiplicity of counter-institutional projects or territories, especially as many rightfully refuse easy categorization and remain illegible (notably within Indigenous territories around the world). Experimenting with lived dynamics to go beyond counter-institutions or duel-power remains an open challenge and question to insurrectionary political ecology.

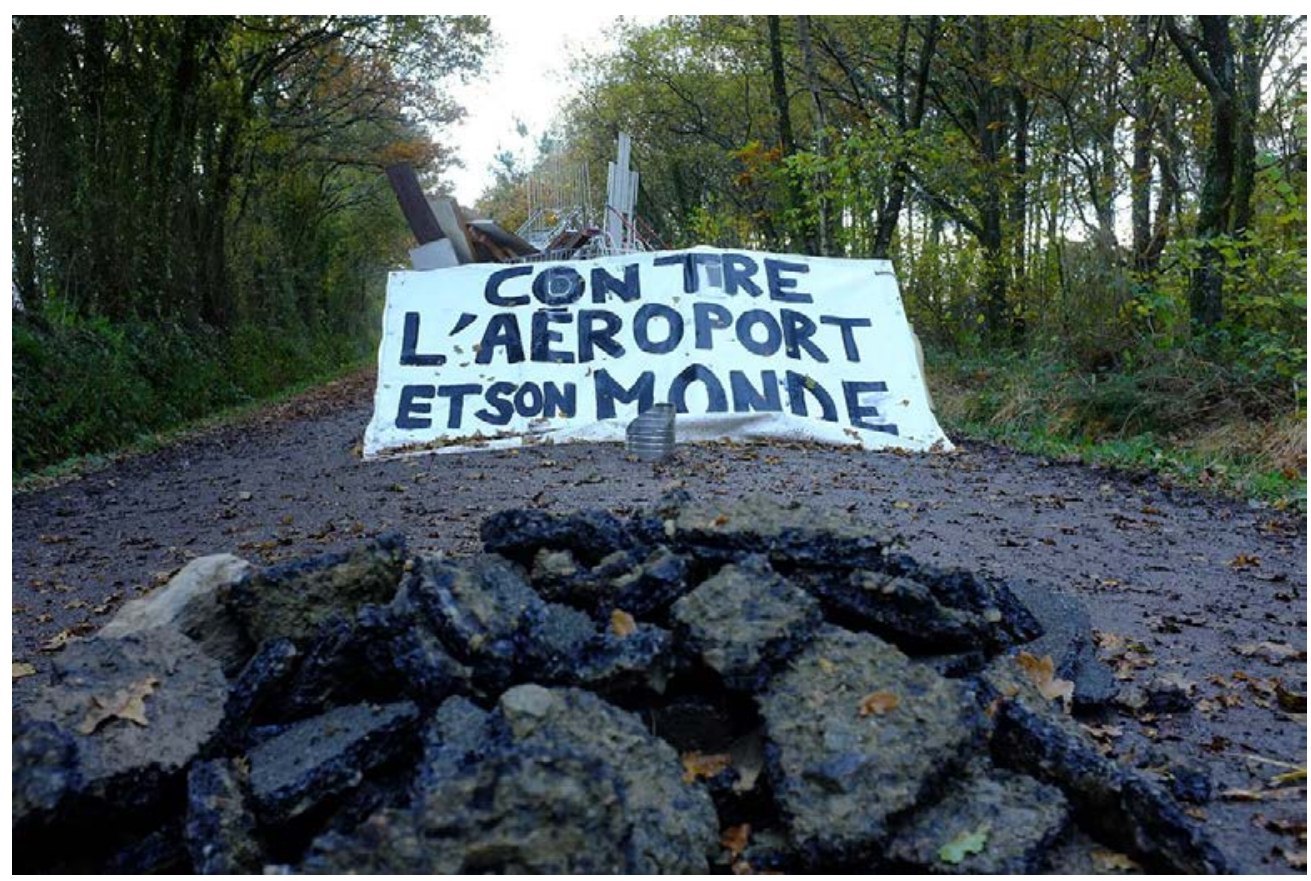

Figure 4. "Against the airport and its world". NDDL ZAD barricade. Source: Wikimedia Commons.

Fukuoka developed a relational, experimental and political practice to live through anti-authoritarian farming, confronting invasive colonial-industrial and techno-capitalist relationships and infrastructures. Similarly, insurrectionary anarchism is not a solution or a program, but a lived pathway to explore in everyday life through observation, experimentation and practice. It relies on informal organizing in a highly debated (and evolving) practice (see Anonymous 2011; Weir et al. 2015), challenging colonial forms of organization by emphasizing affinity and fluidity while creating relationships that aim beyond the assembly, the "working group", and consensus decision making. Informal organizing attempts to bypass the seeds of bureaucracy by organizing outside managerial structures and their hierarchical relationships. All sensitive and relational developments are contingent on environments, and on the social bonds created. Insurrectionary political ecology complements resilience research conceived as resistance to domination (Mullenite 2016) that "generates new forms of life" (Wakefield 2017: 13), as opposed to normalizing the political economy of exploitation. Fukuoka and insurrectionary anarchism can provide pathways of resilience for considering how to politically and ecologically organize with minimal effort, maintain low-logistical overhead and remain evasive. If the building of "counter-institutions" happens, arguably, it is best to keep them illegible to authorities and attentive to concentrations of power.

The idea suggested here is to embody a set of ecologically anti-authoritarian values realized by people in their own way, with neighbors, friends, affinity groups that are not restricted to assembly structures to achieve socio-ecological harmony (see also Trainer 2019b). Viral subversion and unmediated organizational strategies remain advisable and are in need of further theorization and experimentation to develop an insurrectionary 
political ecology. We can conclude, however, that in matters of radical ecological social change, we need the "knife" and "virus" to work together-at least informally or in critical solidarity-to subvert the present trajectory of socio-ecological and climate crisis: to transform catastrophe into opportunities for positive socioecological transformation. Although this is already the case in many places, the proposal of insurrectionary political ecology is to sharpen the clarity of radical directional intention and debate. The proposal is not necessarily creating infrastructure but creating liberated lives and habitats. Physical and immaterial infrastructures need to work for people, and not the other way around.

\section{Conclusion}

This article is a contribution to critical academic inquiry, as it explores and unites the idea of insurrectionary anarchism and no-till natural farming to forge insurrectionary political ecology. As the title suggests, political ecology comes to daggers with Fukuoka, confronting political ecology with radical permaculture and anarchist practices with the hopes of widening political ecology debates. This confrontation, or dance with inflammatory ideas, also intends to strengthen the connections between an anti-authoritarian gardening with anarchist practice, that can spread militant organizational practices to permaculture gardeners. The direction for insurrectionary political ecology seeks to honor a "diversity of actions", "brisantic politics" (Truscello 2020) and other theories (Loadenthal and Rekow, 2020). The article strengthens existing critical schools of thought: insurrectionary political ecology relates to (decolonial) degrowth and post-development, while also linking them to scholarly rebels in political and ecological struggle outside the university system. The widespread use of counterinsurgency, astroturfing and "participatory" strategies to maintain political control and market development (see Brock and Dunlap 2018; Dunlap 2020a), means political ecologists will continue to critically reflect on (mainstream) social movements, development programs and, to some degree, even environmental justice (see Álvarez and Coolsaet 2020). A critical response calls for critically reflection on the role of "professional activists" —as well as academics - "movement leaders" or, pejoratively, "politicians" on the micro, meso and macro scale as they reproduce the habits and relationships of celebrity culture that entails the reproduction of market and technological relationships. The purpose is to offer theoretical ethos for a political ecology of resistance that invigorates a political praxis aiming to subvert social control and ecological catastrophe.

In the end, it is worth considering a criterion to gauge our struggles. This criterion centers on the quality of human and nonhuman relationships; quality of soil, air, water and freedom. ${ }^{23}$ Furthermore, Peter Gelderloos (2013: 48) offers four points to gauge the success of anti-authoritarian political struggles:

1) whether a movement seized space for new social relations;

2) whether it spread an awareness of new ideas (and secondarily if this awareness was passive or whether it inspired others to fight);

3) whether it had elite support;

4) whether it achieved any concrete gains in improving people's lives.

Point three recognizes that movements, often nonviolent ones, with elite support are frequently paraded as being successful, when in actuality this is rather limited from an autonomous or anarchist point of view (see Gelderloos 2013: chapter 3). The challenge of insurrectionary political ecology is to support and develop (individual or collective) struggle to advance anti-authoritarian socio-cultural values that support, if not strengthen, trajectories of (decolonial) degrowth and post-development. Socio-ecological liberation is challenging, in the face of institutional disciplining, the advertising of extravagance and systemic governmentality mechanisms - or social technologies of pacification — designed to condition our subjectivities and struggles. Exercises in illegality will demonstrate the visceral stress programmed into people from birth. Breaking laws, even by petty actions such as spray-painting walls or spreading guerrilla gardens, will reveal

\footnotetext{
${ }^{23}$ This is not to suggest the toleration of fascist and authoritarian ideology, but devising ways to demonstrate how they are unhealthy and harmful and to approach the issues in context.
} 
how unfree and "kept" people have become. Moreover, the secret is to not only begin, but also to break our separation from "nature" and unite our radical theories with a practice built on experimentation, joy, freedom from institutions, friendship and mutual aid. Easier said than done, yet the general direction of our collective priority remains an anti-authoritarian ecological insurrection that political ecology can nurture and expand, while protecting ecosystems and rehabilitating relationships to create liberated habitats in the widest sense.

\section{References}

Aguilar-Støen, M. 2015. Staying the same: transnational élites, mining and environmental governance in Guatemala. In Bull, B. and M. Aguilar-Støen (eds). Environmental politics in Latin America. London: Routledge. Pp. 149-167.

Álvarez, L. and B. Coolsaet. 2020. Decolonizing environmental justice studies: a Latin American perspective. Capitalism Nature Socialism 31(2): 50-69.

Andrew X. 2009 [1999]. Give up activism. Do or Die. Available at: https://theanarchistlibrary.org/library/andrew-X-give-up-activism

Anonymous. 2003. Activist practice and revolutionary struggle. Vancouver Anarchist Online Archive, Available at: https://vanarchive.wordpress.com/2009/11/18/activist-practice-and-revolutionarystruggle-2003

Anonymous. 2011. Letter to the anarchist galaxy. The Anarchist Library. Available at: https://theanarchistlibrary.org/library/anonymous-letter-to-the-anarchist-galaxy

Anonymous. 2016. To the customers: insurrection and doublethink. Berkeley: Ardent Press.

Anonymous. 2018a. Journey towards the Abyss: scattered reflections on the technoworld. Amsterdam: Hourriya.

Anonymous. 2018b. Autonomously and with conviction: a Metis refusal of state-led reconciliation. North Shore Info. Available at: https://north-shore.info/wp-content/uploads/2018/10/reconciliation.pdf

Anonymous. n.d. Insurrectionary ecology: a document for dissemination and discussion. https://www.sproutdistro.com/catalog/zines/theory/insurrectionary-ecology

Aragorn! 2015. NAASN 2015: Christian. Aragorn! Blog. Available at: http://aragorn.anarchyplanet.org/tag/christian/.

Augé, M. 2008 [1995]. Non-places: an introduction to supermodernity. New York: Verso.

Bebbington, A.J. and J. Bury (eds.). 2013. Subterranean struggles: new dynamics of mining, oil, and gas in Latin America. Austin: University of Texas Press.

Berlan, A. 2016. The territorial struggles in front of the state, between protest and co-management. Ecologie et Politique 2(53): 105-128.

Berman, E. 1983. The ideology of philanthropy. Albany: State University of New York Press.

Best, S. and A.J. Nocella. 2006. Igniting a revolution: voices in defense of the earth. Oakland: AK Press.

Black, B. 1986 The abolition of work and other essays. Port Townsend: Loompanics Unlimited.

Black Seed. 2014 - Present. Black seed: a journal of indigenous anarchy. Available at: http://blackseed.anarchyplanet.org

Bonanno, A.M. 1998a [1977]. Armed joy. Elephant Editions.

Bonanno, A.M. 1998b [1996]. The anarchist tension. Elephant Editions.

Bonanno, A.M. 2013 [1995]. Let's destroy work, let's destroy the economy. Berkeley: Ardent Press.

Bookchin, M. 1991. Defending the earth: debate between Murray Bookchin and Dave Foreman. Montreal: Black Rose Books.

Boot M. 2013. Invisible armies: an epic history of guerrilla warfare from ancient times to the present. New York: Liveright Publishing.

Brock, A. 2020. 'Frack off': towards an anarchist political ecology critique of corporate and state responses to anti-fracking resistance in the UK. Political Geography 82: 1-15. 
Brock, A. and A. Dunlap. 2018. Normalising corporate counterinsurgency: engineering consent, managing resistance and greening destruction around the Hambach coal mine and beyond. Political Geography 62(1): 33-47.

Büscher, B. and R. Fletcher. 2020. The conservation revolution: radical ideas for saving nature beyond the Anthropocene. New York: Verso.

Bædan. 2014. Bcedan 2: a queer journal of heresy 2: 1-198.

Churchill, W. 2003. Acts of rebellion: the Ward Churchill reader. London: Routledge.

Clark, J.P. 2019. Between earth and empire: from the Necrocene to the beloved community. Oakland: PM Press.

Crimethinc. 2019. Reflections on the ZAD: another history. https://crimethinc.com/2019/04/23/reflections-onthe-zad-looking-back-a-year-after-the-evictions.

Daggett, C.N. 2019. The birth of energy: fossil fuels, thermodynamics, and the politics of work. Durham: Duke University Press.

Dalakoglou, D. 2017. The road: an ethnography of (im)mobility, space, and cross-border infrastructures in the Balkans. Manchester: Manchester University Press.

D'Alisa, G., F. Demaria and G. Kallis. 2014. Degrowth: a vocabulary for a new era. London: Routledge. Academia

Deloria, V. 1999. Spirit and reason: the Vine Deloria, Jr. reader. Golden: Fulcrum Publishing.

Dirik D., D.L. Strauss, M.T. Taussig and P.L. Wilson. 2016. To dare imagining: Rojava revolution. New York: Autonomedia.

Dunlap, A. 2014b. Permanent war: grids, boomerangs, and counterinsurgency. Anarchist Studies 22(2): 55-79.

Dunlap, A. 2018a. Insurrection for land, sea and dignity: resistance and autonomy against wind energy in Álvaro Obregón, Mexico Journal of Political Ecology 25(1): 120-143.

Dunlap, A. 2018b. Reconsidering the logistics of autonomy: ecological autonomy, self-defense and the polícia comunitaria in Álvaro Obregón, Mexico. Emancipatory Rural Politics Initiative (ERPI), Available at: https://www.tni.org/files/article-downloads/erpi_cp_8_dunlap.pdf.

Dunlap, A. 2018c. Book review: the anarchist roots of geography: toward spatial emancipation by Simon Springer. Human Geography 11(2): 62-64.

Dunlap, A. 2019a. 'Agro sí, mina NO!' The Tía Maria copper mine, state terrorism and social war by every means in the Tambo Valley, Peru. Political Geography 71(1): 10-25.

Dunlap, A. 2019b. Renewing destruction: wind energy development, conflict and resistance in a Latin American context. London: Rowman \& Littlefield.

Dunlap, A. 2019c. Revisiting the wind energy conflict in Gui'Xhi' Ro / Álvaro Obregón: interview with an indigenous anarchist. Journal of Political Ecology 26(1): 150-166.

Dunlap, A. 2020a. Wind, coal, and copper: the politics of land grabbing, counterinsurgency, and the social engineering of extraction. Globalizations 17(4): 661-682.

Dunlap, A. 2020b. Bureaucratic land grabbing for infrastructural colonization: renewable energy, L'Amassada and resistance in southern France. Human Geography 13(2): 1-18.

Dunlap A. 2020c. The politics of ecocide, genocide and megaprojects: interrogating natural resource extraction, identity and the normalization of erasure. Journal of Genocide Research https://doi.org/10.1080/14623528.2020.1754051.

Dunlap, A. 2020. Compost the colony: exploring anarchist decolonization. Tvergastein Journal 15(1): 1-6. Available at: https://medium.com/tvergastein-journal/compost-the-colony-exploring-anarchistdecolonization-5e3f4301664a

Dunlap, A and Jakobsen J. 2020. The violent technologies of extraction: political ecology, critical agrarian studies and the capitalist Worldeater. London: Palgrave.

Elmhirst, R. 2011. Introducing new feminist political ecologies. Geoforum 42(2): 129-132.

Escobar, A. 2008. Territories of difference: place, movements, life, redes. Durham: Duke University Press. 
Escobar, A. 2012 [1995]. Encountering development. Princeton: Princeton University Press.

Evans, I., L. Smiley and M.G. Smith. 2002. The hand-sculpted house: a philosophical and practical guide to building a cob cottage. White River Junction: Chelsea Green.

Federici, S. 2009 [2004]. Caliban and the witch: women, the body and primitive accumulation. New York: Autonomedia.

Fiebrig I., M. Schnyder and J. Anger. 2013. Edible cities: urban permaculture for gardens, balconies, rooftops and beyond. London: Permanent Publications.

Flachs, A. and P. Richards. 2018. Playing development roles: the political ecology of performance in agricultural development. Journal of Political Ecology 25(1): 638-646.

Foucault M. 2003 [1997]. "Society must be defended": Lectures at the College De France 1975-1976. New York: Picador.

Foucault, M. 2007 [1978]. Security, territory, population: lectures at the College De France 1977-1978. New York: Picador.

Fox J.B. 2009. Indigenous science. Cultural Survival Quarterly 33(1): 14-20.

Fukuoka, M. 2010 [1978]. The one-straw revolution: an introduction to natural farming. New York: New York Review of Books.

Fukuoka, M. 2012. Sowing seeds in the desert: natural farming, global restoration, and ultimate food security. White River Junction: Chelsea Green.

Green Anarchy Magazine. 2005. What is green anarchy? An introduction to anti-civilization anarchist thought and practice. Green Anarchy Collective. Available at: https://theanarchistlibrary.org/library/anonymouswhat-is-green-anarchy

Green Anarchy Magazine. 2012. Uncivilized: the best of green anarchy. Berkeley: Ardent Press.

Gardenyes, J. 2011. 23 Tesis en torno a la revuelta. JosepGardenyes, Available at: https://josepgardenyes.files.wordpress.com/2012/09/23tesis.pdf

Gardenyes, J. 2012. Social war, anti-social tension. The Anarchist Library. Available at: https://theanarchistlibrary.org/library/distro-josep-gardenyes-social-war-antisocial-tension

Gelderloos, P. 2013. The failure of nonviolence. Seattle: Left Bank Books.

Gelderloos, P. 2017. Worshiping power: an anarchist view of early state formation. Oakland: AK Press.

Goldman, M. 2010. Diary of a domestic extremist: why I hate activism. Cease Fire Magazine. Available at: https://ceasefiremagazine.co.uk/diary-of-a-domestic-extremist-on-activism

González-Hidalgo, M. and C. Zografos. 2017. How sovereignty claims and "negative" emotions influence the process of subject-making: Evidence from a case of conflict over tree plantations from Southern Chile. Geoforum 78: 61-73.

Gorrion, A. 2015. Science. Anvil Review. Available at: https://theanvilreview.org/print/science

Harvey, D. 2017. 'Listen, Anarchist!' A personal response to Simon Springer's 'Why a radical geography must be anarchist'. Dialogues in Human Geography 7(3): 233-250.

Hatfield, S.C., E. Marino, K.P. Whyte, K.D. Dello and P.W. Mote. 2018. Indian time: time, seasonality, and culture in traditional ecological knowledge of climate change. Ecological Processes 7(1): 1-11.

Hemenway, T. 2009. Gaia's garden: a guide to home-scale permaculture. White River Junction: Chelsea Green.

Hemenway, T. 2015. The permaculture city: regenerative design for urban, suburban, and town resilience. White River Junction: Chelsea Green.

Heynen, N. and L.V. Sant. 2015. Political ecologies of activism and direct action politics. In Perreault T., G. Bridge and J. McCarthy (eds.). The Routledge handbook of political ecology. London: Routledge. Pp. 169-178.

Holloway, J. 2010. Crack capitalism. London: Pluto.

IAM. 2014. Accomplices not allies: abolishing the ally industrial complex. Indigenous Action Media. Available at: http://www.indigenousaction.org/accomplices-not-allies-abolishing-the-ally-industrial-complex/. 
Illich, I. 1970. Planned poverty: the end result of technical assistance. In Illich, I. Celebration of awareness. London: Marion Boyars.

Illich, I. 1973. Tools for conviviality. London: Calder and Boyars.

Illich, I. 1977. Disabling professions. London: Marion Boyars.

Illich, I. 1978. Towards a history of needs. New York: Pantheon.

Illich, I. 2002 [1970]. Deschooling society London: Calder and Boyars.

Jacke, D. and E. Toensmeier. 2005. Edible forest gardens, Volume I and II: ecological design and practice for temperate-climate permaculture. Burlington: Chelsea Green.

Jackson, N.A. 2017. "Social movement theory" as a baseline legitimizing narrative: corporate exploitation, antihegemonic opposition and the contested academy. Human Geography 10(1): 36-49.

Jason, M. 2015. Capitalism in the web of life: ecology and the accumulation of capital. New York: Verso.

Katsiaficas G. 2006 [1997]. The subversion of politics: European autonomous social movements and the decolonization of everyday life. Oakland: AK Press.

Klein, E. and C.E. Morreo. 2019. Postdevelopment in practice: alternatives, economies, ontologies. London: Routledge.

Kothari, A., F. Demaria and A. Acosta. 2014. Buen Vivir, degrowth and ecological Swaraj: alternatives to sustainable development and the green economy. Development 57(3-4): 362-375.

Kothari, A., A. Salleh and A. Escobar, F. Demaria and A. Acosta. 2018. Pluriverse: a post-development dictionary. Delhi: University of Colombia Press.

Landstreicher, W. 2009a. Willful disobedience. Berkeley: Ardent Press.

Landstreicher, W. 2009b Barbaric thoughts: on a revolutionary critique of civilization. In Willful disobedience Berkeley: Ardent Press.

Landstreicher, W. 2011. A sales pitch for the insurrection ${ }^{\mathrm{TM}}$ : a critical look at the coming insurrection. Anarchy: a Journal of Desire Armed. Available at: https://theanarchistlibrary.org/library/wolfi-landstreicher-apioludd-feral-faun-a-sales-pitch-for-the-insurrection.pdf.

Leff, E. 2015. The power-full distribution of knowledge in political ecology: a view from the South. In Perreault T, G. Bridge and J. McCarthy (eds). The Routledge handbook of political ecology. London: Routledge. Pp. 64-75.

Lewis, A.G. 2017. Imagining autonomy on stolen land: settler colonialism, anarchism and the possibilities of decolonization? Settler Colonial Studies 7(4): 474-495.

Loadenthal, M. 2017. The politics of the attack: communiqués and insurrectionary violence. Manchester: Manchester University Press.

Loadenthal, M. and L. Rekow. 2020. From environmental loss to resistance: infrastructure and the struggle for justice in America. Amherst: University of Massachusetts Press.

London, J.K. 1998. Common roots and entangled limbs: Earth First! and the growth of post-wilderness environmentalism on California's north coast. Antipode 30(2): 155-176.

Lockyer, J. 2017. Community, commons, and degrowth at Dancing Rabbit Ecovillage. Journal of Political Ecology 24(1): 519-542.

López, C. 2014. Mexican prisons: "that which stagnates rots". War on Society. Available at: https://waronsociety.noblogs.org/?p=9219.

Mann, S. and E. Hughes. 2015. Episode 1523: necessary simplicity with Ethan Hughes. The Permaculture Podcast. Available at: https://www.thepermaculturepodcast.com/2015/episode-1523-ethan-hughes

Martínez-Alier, J. 2002. The environmentalism of the poor: a study of ecological conflicts and valuation. Northampton: Edward Elgar.

Mbembe, A. 2019 Necropolitics. Durham: Duke University Press.

Merchant, C. 1983. The death of nature: women, ecology, and the scientific revolution. New York: Harper and Row. 
Mignolo, W.D. 2005. The idea of Latin America. Malden: Wiley.

Mullenite J. 2016. Resilience, political ecology, and power: convergences, divergences, and the potential for a postanarchist geographical imagination. Geography Compass 10(9): 378-388.

Newell, P. 2009. Bio-hegemony: the political economy of agricultural biotechnology in Argentina. Journal of Latin American Studies 47(1): 27-57.

Nirmal, P. and D.E. Rocheleau. 2019. Decolonizing degrowth in the post-development convergence: questions, experiences, and proposals from two Indigenous territories. Environment and Planning E 2(3): 465-492.

Passami, M. 2014. Freedom's disorder: a collection of texts by Massimo Passamani. Amsterdam: Roofdruk Edities.

Peet, R. and M.J. Watts (eds.). 2004. Liberation ecologies. London: Routledge.

Pellow, D.N. 2014. Total liberation: the power and promise of animal rights and the radical earth movement. Minneapolis: University of Minnesota Press.

Perreault, T., G. Bridge and J. McCarthy J. (eds.). 2015. The Routledge handbook of political ecology. London: Routledge.

Porto, M.F., D.R. Ferreira and R. Finamore. 2017. Health as dignity: political ecology, epistemology and challenges to environmental justice movements. Journal of Political Ecology 24(1): 110-124.

Rahnema, M. 1991. Global poverty: A pauperizing myth. Interculture 24(3): 4-51.

Rahnema, M. and V. Bawtree. 1997. The post-development reader. London: Zed.

Ramnath, M. 2012. Decolonizing anarchism: an antiauthoritarian history of India's liberation struggle. Oakland: AK Press.

Return Fire Magazine. 2013-present. Available at: http://returnfire.noblogs.org

Robbins, P. 2004. Political ecology: a critical introduction. Oxford: Blackwell.

Rocheleau, D.E. 2015. Networked, rooted and territorial: green grabbing and resistance in Chiapas. The Journal of Peasant Studies 42(3-4): 695-723.

Rodríguez G. 2014. Anarchist dialogues: a conversation with Gustavo Rodriguez. Conspiración Acrata Available at: https://en-contrainfo.espivblogs.net/files/2014/04/dialoguesgustavorodriguez.pdf

Roman-Alcalá A. 2020. Agrarian anarchism and authoritarian populism: towards a more (state-) critical 'critical agrarian studies.' The Journal of Peasant Studies https://doi.org/10.1080/03066150.2020.1755840

Rosset, P.M. and M.A. Altieri. 2017. Agroecology: science and politics. Rugby: Practical Action Publishing.

Sale, K. 2000 [1991]. Dwellers in the land: The bioregional vision. Athens: University of Georgia Press.

Sasha K. 2001. Some notes on insurrectionary anarchism. Killing King Abacus 2: 2-4.

Schumacher, E.F. 1973. Small is beautiful. London: Blond and Briggs.

Schwarz, A., T. Sagris and V. Network. 2010. We are an image from the future: the Greek revolt of December 2008. Oakland: AK Press.

Scott, J.C. 2009. The art of not being governed: an anarchist history of upland Southeast Asia. New Haven: Yale University Press.

Seeweed. 2013. Land and freedom: an open invitation. Berkeley: Black Powder Press.

Shiva, V. 2002 [1989]. Staying alive: women, ecology and development. London: Zed.

Springer, S. 2014. Why a radical geography must be anarchist. Dialogues in Human Geography 4(3): 249-270.

Springer, S. 2016. The anarchist roots of geography: toward spatial emancipation. Minneapolis: University of Minnesota Press.

Springer, S. 2017. The limits to Marx: David Harvey and the condition of postfraternity. Dialogues in Human Geography 7(3): 280-294.

Springer, S., M. Locret, J. Mateer and M. Acker (eds.). In press. Anarchist political ecology: Volumes 1-4. London: Rowman and Littlefield.

Stirner, M. 2017 [1844]. The unique and its property. Berkeley: Ardent Press. 
Svarstad, H., T.A. Benjaminsen and R. Overå. 2018. Power theories in political ecology. Journal of Political Ecology 25(1): 350-363.

TIC (The Invisible Committee). 2009. The coming insurrection. Los Angeles: Semiotext(e).

TIC (The Invisible Committee). 2015. To our friends. Pasadena: Semiotext(e).

TIC (The Invisible Committee). 2017. Now. Pasadena: Semiotext(e).

Tiqqun. 2011 [1999]. Conscious organ of the imaginary party exercise in critical metaphysics. Berkeley: Ardent Press.

Trainer, T. 2019a. Entering the era of limits and scarcity: the radical implications for social theory. Journal of Political Ecology 26(1): 1-18.

Trainer, T. 2019b. Remaking settlements for sustainability: the Simpler Way. Journal of Political Ecology 26(1): 202-223.

Truscello, M. 2020. Infrastructural Brutalism: art and the necropolitics of infrastructure. Boston: MIT Press.

Tsing, A.L. 2015. The mushroom at the end of the world. Princeton: Princeton University Press.

Ulloa, A. 2014. Estrategias culturales y políticas de manejo de las transformaciones ambientales y climáticas en Colombia. In Lara, R. and R. Vides-Almonacid (eds). Sabiduría y adaptación: el valor del conocimiento tradicional para la adaptación al cambio climático en América del Sur. Quito: IUCN. Pp. $155-175$.

Ulloa, A. 2019. Indigenous knowledge regarding climate in Colombia. In Feola G., H. Geoghegan and A. Arnall (eds). Climate and culture. Cambridge: Cambridge University Press. Pp. 68-92.

Vaneigem, R. 2012 [1967]. The revolution of everyday life. Oakland: PM Press.

Virilio, P. 1990 [1979]. Popular defense and ecological struggles. New York: Semiotext(e).

Wakefield, S. 2018. Inhabiting the Anthropocene back loop. Resilience 6(2): 77-94.

Weir, J. 1990 [1979]. Armed struggle in Italy 1976-78: a chronology. London: Elephant Editions.

Weir, J. 2017. Tame words from a wild heart. London: Active Distribution.

Weir, J., A. Bonanno et al. 2015. Down the Maxi-prison: contributions to the struggle against the construction of a maxi-prison in Brussels. Available at: https://actforfree.nostate.net/wpcontent/uploads/2017/02/down-the-maxi-prison.a4.pdf

Wisner, B. 2015. Speaking truth to power: a personal account of activist political ecology In Perreault T., G. Bridge and J. McCarthy (eds). The Routledge handbook of political ecology. London: Routledge. Pp. 53-63.

Whyte K.P. 2018. Settler colonialism, ecology, and environmental injustice. Environment and Society 9(1): 125-144.

Whyte, K.P., J.P. Brewer and J.T. Johnson. 2016. Weaving Indigenous science, protocols and sustainability science. Sustainability Science 11(1): 25-32.

Zanotti, L., C. Carothers, C.A. Apok, S. Huang, J. Coleman and C. Ambrozek. 2020. Political ecology and decolonial research: co-production with the Iñupiat in Utqiagivik. Journal of Political Ecology 27(1): 4366.

Zerzan, J. 1988. Elements of refusal. Seattle: C.A.L. Press.

Zerzan, J. 2012 Future primitive revisted. Port Townsend: Feral House.

Zibechi, R. 2012. Territories in resistance: a cartography of Latin American social movements. Oakland: AK Press. 